\title{
sir Karl Raimund Popper
}

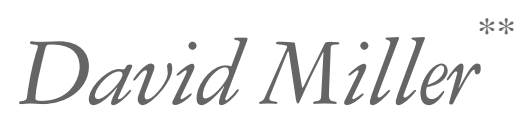

Karl Raimund Popper, filósofo e metodólogo da ci ncia, morreu em 17 de setembro de 1994 aos 92 anos de idade. Locke pertenceu Royal Society, evidentemente, e alguns outros antes dele, Boyle em particular, t $\mathrm{m}$ um lugar seguro na história da filosofia. Whewell, um precursor intelectual de Popper (MeDaWAR 1967), foi eleito em 1820, quando a Royal Society estava, segundo um filósofo contempor neo, 'em estado de equil brio instável'; com apenas 26 anos, ele lecionou matemática e ocupou, posteriormente, a cadeira de mineralogia em Cambridge, alguns anos antes de escrever seus brilhantes estudos sobre história e filosofia da ci ncia. Whitehead e Russell foram eleitos membros por seu trabalho em matemática, como foram também um ou dois lógicos mais recentemente. Popper é o único filósofo, nos tempos modernos, eleito membro da Royal Society principalmente em reconhecimento sua contribuiç o filosófica. ${ }^{\dagger}$

A vida intelectual de Popper estendeu-se por mais de 75 anos, com pouca interrupç o. Ele trabalhou, pensou e escreveu, e repensou e reescreveu, quase incessantemente. Realizou avanços notáveis (em alguns casos revolucionários) em filosofia da ci ncia, teoria da probabilidade, teoria do conhecimento, metaf sica, filosofia social e pol tica e filosofia da história; contribuiu de modo relevante (quase sempre controverso) para a nossa compreens o da lógica, história da filosofia (especialmente dos présocráticos, Plat o e Marx), mec nica clássica, termodin mica clássica, f sica qu ntica, biologia evolucionária, psicologia e música. Como Magee (1997, 
p. 211) escreve: 'Nenhum outro pensador do século XX aproximou-se ... da eficácia [de Popper] como destruidor de mitos predominantes da época ... Até o final de sua vida, ele foi surpreendentemente fértil em idéias novas'. A lista de publicaç es de Popper contém mais de 1200 refer ncias, incluindo reimpress es e traduç es, e seu arquivo (até 1985) ocupava 463 caixas de manuscritos na biblioteca da Instituiç o Hoover na Universidade de Stanford (a Universidade de Klagenfurt na Áustria possui uma fotocópia completa; uma outra cópia é mantida em 473 rolos de microfilme na London School of Economics). O que aqui faremos consiste apenas em identificar os acontecimentos decisivos da vida intelectual e cient fica de Popper, esboçar e avaliar suas principais contribuiç es para a ci ncia e para a compreens o da ci ncia - indicando algumas das numerosas cr ticas a que foram expostas - e, de passagem, revelar alguns aspectos de seu caráter amável embora dif cil.

\section{Em Viena, 1902-36}

Popper nasceu a 28 de julho de 1902, em Himmelhof, Ober St Veit, no extremo oeste de Viena, o único filho do Dr. Simon Siegmund Carl Popper e Jenny Popper (Schiff, quando solteira). Sua irm Dora (Emilie Dorothea) tinha ent o oito anos de idade, sua irm Annie (Anna Lydia), quatro. Seus pais eram judeus, mas se converteram ao protestantismo. Sua $\mathrm{m}$ e, que nasceu em Viena em 1864, veio de uma fam lia com rica formaç o musical; seus pais foram membros fundadores da Gesellschaft der Musikfreunde e ela e suas duas irm s foram talentosas pianistas. O pai de Popper, cuja fam lia veio de Kolin, nasceu em 1856, em Roudnice nad Labem [Raudnitz], que atualmente se localiza na República Tcheca. Ele n o foi educado junto a seus dois irm os, embora os tr $\mathrm{s}$ tenham seguido a mesma carreira, tornando-se advogados pela Universidade de Viena. Foi um homem culto, historiador, poeta, cientista social, 'mais que um advogado, um "scholar"', segundo seu filho. A fam lia de Popper viveu no centro de Viena, no primeiro andar de uma bonita casa do século XVIII, esquina de Freisingergasse e Bauernmarkt, onde o pai de Popper manteve sua bem-sucedida prática do direito (GEIER 1994, p. 39). Nos $§$ 2-6 da sua autobiografia intelectual Unended quest 1976(g) $)^{\dagger \dagger}$, Popper 
escreveu, de maneira comovente, sobre um ou dois episódios de sua inf ncia, e aqui nada mais direi sobre isso.

O pai de Popper morreu em 1932, ano em que Dora Popper (que fora enfermeira e também funcionária pública) suicidou-se, na ocasi o em que foi acometida de uma doença. Popper e sua esposa Hennie (Josefine Anna Henninger, nascida em 1906) deixaram a Áustria em 1937. Sua $\mathrm{m}$ e morreu em 1938, depois de uma longa enfermidade. Cerca de dezesseis membros da fam lia morreram por causa do terror nazista. Um $\mathrm{m} s$ depois da morte de sua m e, Annie Popper fugiu para Paris e, posteriormente, para Su ça, onde viveu até sua morte, nos anos 70. Ela escreveu histórias e novelas rom nticas, uma das quais relata a bravura de uma mulher das selvas.

Dos seis aos onze anos, Popper foi educado em uma escola particular; depois, foi matriculado no Franz Josef Gymnasium [366.3]. Mas ele conta que, extremamente aborrecido com muitas de suas liç es, abandonou, de fato, a escola aos 16 anos. Sua primeira tentativa na Matura - o exame de ingresso na universidade - foi malsucedida, porque ele n o passou em duas disciplinas (uma falha poderia ser desculpada): lógica e latim. Em lógica, ele foi examinado por Edgar Zilsel, que posteriormente tornou-se membro do $\mathrm{C}$ rculo de Viena, de quem ele discordou acerca da lógica aristotélica (provavelmente, acerca do compromisso existencial da quantificaç o universal). O exame de latim exigiu uma traduç o oral de uma ode de Horácio ignorada pelo candidato. $\mathrm{Na}$ segunda tentativa, em 1922, obteve xito; n o houve conflito com o seu examinador de lógica e, talvez, a ode de Horácio fosse menos desconhecida do que a do primeiro exame.

Popper permaneceu na universidade até 1928. Formalmente estudou matemática com Hahn, Helly, Furtw ngler e Menger; f sica com Ehrenhaft, Haas, Lecher e Thirring; psicologia com B hler; e filosofia com Heinrich Gomperz e Schlick. Mas fez muitas outras coisas. Explorou suas habilidades manuais como artes o. $\mathrm{N}$ o obteve xito. Por volta de 1917, esteve ativamente envolvido com a pol tica progressista e, por um curto per odo de tempo, pensou-se como um comunista. Mas depois do fuzilamento impass vel de ativistas desarmados, executados pela pol cia em H rlgasse, em 1919, ele se revoltou com a disposiç o c nica dos marxistas para sacrificar a vida dos outros em favor de ideais indeterminados. 
Apesar dos receios, manteve-se simpático ao movimento social-democrata; e mesmo ao pacifismo, embora jamais tivesse sido um pacifista (KiesewetTer 1997, p. 328). Alguns anos depois de 1920, foi aprendiz de marceneiro. Também n o obteve xito completo. (Anos depois, na Nova Zel ndia, projetou e encomendou belas mob lias em estilo funcional.) Trabalhou na cl nica de orientaç o de crianças de Adler e, depois, desenvolveu um trabalho social com crianças carentes. Em 1923, qualificou-se como professor de escola primária. Em 1922 ou 1923, depois de ouvir a música executada em Verein $f$ r musikalische Privatauff brungen de Schoenberg, e de n o gostar muito, tentou ingressar no Konservatorium de Viena, escrevendo, para esse propósito, uma fuga para órg o em Fá\#menor. Sobre essa fuga, executada publicamente pela primeira vez em 1992 por Dame Gillian Wier, ele disse depois que foi uma tentativa de homenagear Bach pelo seu segundo tema, 'uma menç o de $A$ paix o segundo $S$ o Mateus de Bach' $\left(1992\left(\mathrm{z}_{21}\right)\right)$. Julien Musafia, pianista que fez um arranjo da fuga para quatro $\mathrm{m}$ os, descreve-a como 'uma composiç o de impulso rom ntico com roupagem barroca - teria sido uma peça digna de ser submetida ao final de seus estudos no Konservatorium e n o no in cio' (1996, comunicaç o pessoal). Mas Popper, convencido de que n o era suficientemente talentoso para se tornar um músico profissional, permaneceu por apenas um ano.

Uma década depois, em uma declaraç o acerca dos detalhes de sua educaç o, Popper escreveu [366.3]: '[Em 1925], entendi que as circunst ncias na Áustria n o me permitiriam obter uma posiç o oficial na universidade.' Isso, sem dúvida, alude n o apenas ao predominante sentimento anti-semita, mas também dist ncia de Popper em relaç o a filósofos influentes; naquela época, o meio acad mico era, em sua maior parte, lugar para conservadores, clérigos e católicos, n o sendo adequado para um social-democrata de mentalidade independente como Popper. 'Ent o, decidi me preparar para um posto na escola pública. Assisti a aulas sobre educaç o e comecei a cuidar de quest es pedagógicas ...' A cidade de Viena recentemente abrira seu novo Instituto Pedagógico, no qual Popper se matriculou. Foi lá que ele se encontrou com sua esposa, Hennie, uma estudante de educaç of sica. Assistiu na universidade $\mathrm{s}$ aulas de B hler sobre psicologia e descobriu as doutrinas da escola de W rzburg, especialmente as de $\mathrm{K}$ lpe and Selz. Mas, embora atra do por muitas dessas doutrinas, particularmente a que afirma $\mathrm{n}$ o ser o pensamento 
desenvolvido por meio da associaç o passiva de idéias mas sob o impulso ativo da soluç o de problemas, Popper foi se persuadindo de que a lógica é a chave para a psicologia, e n o o contrário (1972(a), cap tulo 1, §10); de que o desenvolvimento do conhecimento só pode ser entendido se se entender a sua lógica. Sua tese de doutorado de 1928, 'Zur Methodenfrage der Denkpsychologie' ['Sobre o problema do método na psicologia do pensamento'], examinada por B hler (que a elogiou muito [406.1]) e Schlick, o fundador do $\mathrm{C}$ rculo de Viena, marcou um ponto decisivo; depois disso, ele sempre sustentou a concepç o de que o conhecimento cient fico, embora humanamente criado, é conhecimento objetivo e deve ser analisado em termos objetivos. A tese "Gewohnheit" und "Gesetzerlebnis" in der Erziehung' [“"Hábito” e "experi ncia de leis” na educaç o'], submetida ao Instituto Pedagógico em 1927 ou 1928, nunca foi propriamente finalizada.

O interesse de Popper pela lógica e metodologia da ci ncia teve in cio muito antes de sua participaç o nos seminários de B hler. Em mais de uma ocasi o (1963(a), cap tulo 1; 1976(g), §8), ele contou a história de sua compreens o, em 1919, de que o que distingue as melhores teorias cient ficas, as que mais contribuem para o nosso entendimento e nosso conhecimento, $\mathrm{n}$ o é que a experi ncia invariavelmente as confirma, mas que invariavelmente as desafia, expondo-as ao risco do falseamento. Ele comparou a relatividade geral, cuja prediç o ousada de que os raios de luz curvam-se em campos gravitacionais tinha sido recentemente testada pelas observaç es do eclipse, feitas por Eddington, em Sobral e Pr ncipe, com doutrinas pseudocient ficas - ele citou o marxismo vulgar e a psicanálise cuja principal caracter stica parece ser sua habilidade de explicar tudo o que possa ocorrer. As prediç es de alguns astrólogos e cartomantes s o similares, isto é, s o cuidadosa ou ambiguamente expressas de modo que se ajustem a qualquer conting ncia futura. Popper notou que tal flexibilidade, tal habilidade de explicar tudo, seja o que for, n o é uma virtude de uma teoria; ao contrário, revela que a teoria n o exclui nada, que ela n o tem conteúdo emp rico. Na verdade, uma teoria bem-sucedida explica uma grande parte do que de fato acontece dentro de seu dom nio, talvez tudo; o que ela n o deve é explicar tudo o que poderia acontecer. Uma teoria, afirma o critério de demarcaç o de Popper, deve ser, em princ pio, falseável, se pertencer ci ncia emp rica, se disser algo acerca do mundo de que temos experi ncia. Mas, evidentemente, é desejável que, apesar de várias 
tentativas de falseamento, ela n o seja falseada na prática. Para que uma teoria seja informativa, ela deve correr riscos; se for correta, ela deverá sobreviver. Popper atribuiu sua apreciaç o da virtude da especulaç o audaciosa nas hipóteses cient ficas coragem do explorador polar Nansen, um de seus heróis da inf ncia (1994(y), p. 321s.; Kiesewetter, 1997, p. 329). Sua apreciaç o do fato de que uma teoria pode passar por qualquer número de testes e ainda ser falsa, ele a atribuiu superaç o da teoria gravitacional newtoniana pela relatividade geral. De fato, ele freq entemente declarava que, sem a revoluç o de Einstein, teria permanecido um kantiano, convencido de que a mec nica clássica encerrava a verdade final.

Durante esses anos de estudante, a influ ncia filosófica mais duradoura e aquela com que mais simpatizou foi a de Julius Kraft, um filósofo do direito, de G ttingen, que havia estudado com Leonard Nelson. Kraft e Popper mantiveram muitas conversas informais entre 1924 e 1925. Seus argumentos giravam em torno das profundas dificuldades que cada um notava no sintético a priori de Kant, a doutrina segundo a qual podemos conhecer o que realmente conhecemos sobre o mundo da experi ncia somente se algumas das coisas mais fundamentais que conhecemos (por exemplo, que o espaço é tridimensional e euclidiano) estiverem dispon veis a nós independentemente da experi ncia. Do mesmo modo que Kant, Kraft e Popper estavam ansiosos para evitar o abandono cético da racionalidade em que Hume havia ca do, mas discordavam totalmente sobre como evitá-lo (1962(f), p. 4-6) - Popper já reconhecia que algumas das proposiç es sintéticas a priori de Kant tinham sido refutadas. Foi apenas no fim de seus dias de estudante que se lhe tornou claro que se as teorias cient ficas audaciosamente antecipam a experi ncia, elas n o podem estar firmemente fundadas na experi ncia. $\mathrm{O}$ credo tradicional, proclamado por Bacon e institucionalizado por J.S. Mill, segundo o qual a ci ncia parte dos fatos e obtém generalizaç es por um processo de induç o logicamente defensável, deve ser rejeitado tanto em termos psicológicos quanto lógicos. Nossas teorias $\mathrm{n}$ o prov $\mathrm{m}$ da experi ncia nem s o sempre geradas por ela. Psicologicamente, as teorias s o conjecturas, suposiç es cujo papel - como a escola de W rzburg enfatizava - é solucionar problemas, sondar o desconhecido e n o apenas organizar o que já é conhecido (que, por sua vez, também pode ser admitido, em certos casos, como um problema). O mesmo vale para a lógica. Nenhuma teoria 
universal ou prediç o se segue de fatos conhecidos por algum processo lógico (Hume mostrara isto 150 anos antes); $n$ o existe $l$ gica indutiva. Fatos, observaç es, experimentos - estes servem ci ncia n o como um fundamento, ou mesmo como um suporte, para a superestrutura teórica, mas apenas como testes de sua correç o. Embora nenhuma acumulaç o de experi ncias possa verificar uma teoria universal, ou mesmo fornecer raz es para a supor verdadeira, um contra-exemplo, se mantido, irá falseá-la.

Esse, em s ntese, é o método de conjecturas e refutaç es, a soluç o de Popper para o problema da induç o, sua resoluç o do problema kantiano de como os componentes intelectual (a priori) e emp rico (a posteriori) do conhecimento humano est o integrados. Muito criticado e infindavelmente dissecado nos últimos 70 anos, ele agradou aos cientistas ao insistir em que o trabalho deles é inventivo e imaginativo; confortou aqueles levados a acreditar que apenas o inapto comete enganos; e animou aqueles perturbados com o ceticismo humeano acerca da induç o. $N$ ob induç 0 . Tampouco $b$ necessidade do ceticismo. Nosso conhecimento pode desenvolverse desde que renunciemos demanda tradicional por teorias que sejam verificadas, provadas ou justificadas, e perguntemos apenas se elas s o corretas. Uma opini o correta n o está além de nós, se temos sorte, embora jamais possamos estar seguros de que possu mos uma. A descoberta cient fica difere do saber do senso comum (e mesmo do animal) n o, como Bacon pensava, por evitar partipris e preconceito, pois os cientistas também $\mathrm{d}$ o saltos para as conclus es. A diferença é que uma conclus o cient fica marca o in cio da investigaç o, n o o seu fim; é por meio do uso autoconsciente do método cr tico de identificar e eliminar erros que o pensamento cient fico (de modo mais geral, o pensamento racional) distingue-se do pensamento animal; 'de uma ameba a Einstein há só um passo' (1972(a), cap tulo 6, §xx).

Em 1929, Popper apresentou ao Instituto Pedagógico uma terceira tese, intitulada 'Axiome, Definitionen und Postulate der Geometrie' ['Axiomas, definiç es e postulados da geometria'] [4.6], para se qualificar como um professor de ci ncia em escolas secundárias, e em 1930, ano de seu casamento, foi indicado para seu primeiro posto no ensino oficial. Continuou a pensar e a escrever ininterruptamente. Por volta dessa época, encontrou-se com Herbert Feigl, um dos mais jovens membros do C rculo de Viena. Esse grupo, algumas vezes conhecido como "positivis- 
tas lógicos' ou 'empiristas lógicos', combinava um entusiasmo pela lógica-matemática contempor nea com a nfase positivista tradicional na certeza e na prioridade epistemológica da experi ncia sensorial. Embora as concepç es de Popper sobre a demarcaç o e a induç o tivessem sido desenvolvidas, em parte nas discuss es com Kraft, como uma extens o e correç o das filosofias de Kant, Fries e Nelson, e n o deliberadamente em oposiç o s idéias do $\mathrm{C}$ rculo de Viena, ele já tinha conhecimento de que elas eram conflitantes em vários pontos com as concepç es do $\mathrm{C}$ rculo, preeminentemente com sua doutrina (derivada de Wittgenstein, que $\mathrm{n} o$ era um membro do $\mathrm{C}$ rculo) de que a verificabilidade emp rica fornece um critério de significatividade (e a conseq ncia de que a metaf sica carece de significado). Feigl o persuadiu de que suas cr ticas ao $\mathrm{C}$ rculo eram t o significativas que deveriam ser publicadas em um livro. Como resposta, Popper, que até ent o havia publicado apenas pequenos artigos sobre assuntos relacionados educaç o, planejou um gigantesco trabalho, Die beiden Grundprobleme der Erkenntnistheorie [Os dois problemas fundamentais da teoria do conhecimento], em dois volumes, intitulados Das Induktionsproblem [O problema da induç o] e Das Abgrenzungsproblem [O problema da demarcaç o]. Jamais completamente finalizado, ele foi resumido, depois estendido e, por fim, resumido novamente. O resultado foi Logik der Forschung 1934(b), traduzido para o ingl s como The logic of scientific discovery 1959(a). O que sobreviveu dos dois volumes originais de texto datilografado foi publicado como $1979\left(\mathrm{z}_{2}\right)$, mas ainda $\mathrm{n}$ o se encontra dispon vel em ingl s. $\mathrm{N}$ o se conhece o destino do texto intermediário datilografado (Hansen 1974).

\section{Logik der Forschung}

Os cap tulos que abrem Logik der Forschung enunciam com muita clareza e concis o todas as teses centrais do falseacionismo, a metodologia de conjecturas e refutaç es. (a) A induç o n o é apenas falaciosa, mas desnecessária. O assim chamado método indutivo é substitu do pelo ' $m$ todo dedutivo de teste, ... a concepç o segundo a qual uma hipótese somente pode ser testada empiricamente - e só depois dela ter sido formulada' $(\$ 1)$. (b) As hipóteses devem ser consideradas cient ficas se e somente se elas 
forem empiricamente falseáveis. Admite-se que qualquer hipótese pode escapar do falseamento por meio de ajustes suficientemente drásticos, por exemplo, postulando ad hoc a exist ncia de entidades ou efeitos anteriormente desconhecidos; mas está no cerne da abordagem cient fica, se n o em sua prática invariante, excluir táticas evasivas desse tipo (§6). (c) Se quisermos que a ci ncia progrida, $\mathrm{n}$ o devemos temer os erros, mas adotar regras metodológicas cujo objetivo maior seja encorajar o falseamento de nossas teorias e a eliminaç o de seus erros (§11). (d) A metodologia n o deve ser identificada com a disciplina emp rica que descreve como os cientistas se comportam, como fizeram os positivistas, pois mesmo a demarcaç o subjacente dos cientistas em relaç o a outros depende da adoç o de uma decis o ou convenç o (\$4). (e) Os próprios enunciados básicos com os quais as teorias cient ficas s o confrontadas nos testes s o conjecturais; a ci ncia n o apela a percepç es ou enunciados de percepç o incorrig veis e 'a base emp rica' n o é um ponto de parada absoluto mas convencional - embora esteja longe de ser arbitrário. Assim sendo, nenhum falseamento é conclusivo (mas isso n o o impede de ser um falseamento): 'Se insistirmos em ... refutaç o estrita ... nas ci ncias emp ricas, jamais nos beneficiaremos da experi ncia e nunca aprenderemos com ela o quanto estamos errados’ ( 99$)$. Os outros cap tulos desenvolvem essas e outras teses.

Um dos principais tópicos do livro é a probabilidade. Popper notou no $\$ 34$ que a palavra 'probabilidade' possui muitos significados e distinguiu a probabilidade f sica de um evento ou tipo de evento da que chamou de probabilidade lógica de um enunciado ou teoria, que ele mostrou estar inversamente relacionada com seu conteúdo emp rico e com seu grau de falseabilidade: quanto mais uma teoria diz, mais ela pro be, mais oportunidades ela oferece ao falseamento e menor a probabilidade de ela ser verdadeira. Ele afirmou, como uma conseq ncia imediata, que a ci ncia n o pode estar interessada em obter teorias prováveis ( $\$ 83)$. Em um extenso cap tulo dedicado probabilidade $\mathrm{f}$ sica, ele descartou as apologias subjetivistas que a explicam como n o mais do que uma compensaç o da ignor ncia e se dedicou a dois problemas centrais na única teoria objetivista existente, a de von Mises, segundo a qual as probabilidades s o os limites para as quais as freq ncias relativas tendem em classes de refer ncia aleatórias indefinidamente longas (coletivos). $O$ problema da decidibilidade pergunta como os enunciados de probabilidade, 
que s o 'em princ pio imunes ao falseamento estrito' (Prefácio ao cap tulo VIII), podem, n o obstante isso, pertencer ci ncia emp rica; um desafio crucial ao critério de demarcaç o. O problema fundamental da teoria do acaso (§49) pede por uma explicaç o de por que as seq ncias aleatórias s o estatisticamente estáveis. (Mises oferece pouco aqui, uma vez que os coletivos s o definidos como seq ncias aleatórias e estáveis.) Popper prop s duas soluç es ao problema da decidibilidade, que n o est o em total harmonia. Uma, bem de acordo com os procedimentos da estat stica clássica, envolve a adoç o de regras metodológicas para permitir o falseamento de enunciados de probabilidade ou estat sticos. A outra, mais original, mostra que a própria atribuiç o de aleatoriedade é falseável se estendemos a idéia a seq ncias finitas. Embora o tratamento de Popper das seq ncias aleatórias finitas, um dos primeiros, n o seja completamente satisfatório (Ville 1939; Delahaye 1994, p. 35), ele também sugere uma soluç o ao problema fundamental da teoria do acaso; pois, como ele mostrou, as seq ncias que s o aleatórias desde o in cio s o sempre estatisticamente estáveis.

Apesar da popularidade do critério de verificabilidade do significado, concedia-se normalmente que nenhuma quantidade de evid ncia emp rica pode transformar uma teoria cient fica em uma certeza; muitos filósofos, mesmo no $\mathrm{C}$ rculo de Viena, eram falibilistas com respeito a teorias, mas n o quanto a enunciados de evid ncia. Afirmava-se, contudo, e ainda se afirma, que é poss vel aproximar-se da certeza; as teorias podem tornar-se cada vez mais prováveis (no sentido da probabilidade lógica) e, desse modo, o problema do aprendizado a partir da experi ncia, que é id ntico ao problema da induç o, estaria solucionado. A probabilidade condicional $p(b \mid e)$ (ou relativa, como Popper preferiu chamá-la) de uma hipótese ou teoria $h$ em relaç o evid ncia $e$ foi tratada como uma medida da dedutibilidade parcial de $h$ a partir de $e$ (variando da unidade, quando $b$ é dedut vel de $e$, até zero, quando $b$ contradiz $e$ ); e - supondo que a induç o é deduç o generalizada - pensou-se, portanto, que $p(b \mid e)$ mede adequadamente o grau em que $b$ é empiricamente ou indutivamente sustentada por $e$. No último cap tulo do livro, Popper repudia, com detalhe, a concepç o, especialmente como desenvolvida por Reichenbach e Keynes, segundo a qual o problema da induç o pode ser resolvido com a introduç o de consideraç es de probabilidade. Há tr s itens em quest o aqui: a probabilidade atual $p(b \mid e)$ da teoria $b$; o grau com que $b$ tem resistido aos 
testes cujos resultados s o descritos por $e$ (que Popper chamou grau de corroboraç o de $h$ ); e o que $e$ nos diz sobre o valor de verdade de $h$. Popper argumentou que os dois primeiros s o distintos e, a menos que a teoria seja refutada, que nenhum deles é uma medida do terceiro; pois a evid ncia emp rica nada pode nos ensinar acerca de uma teoria, exceto que ela é falsa. Nos anos seguintes, a cr tica aos apelos probabilidade passou a ser um tema constante em seus insistentes ataques filosofia da induç o.

Logik der Forchung contém também um cap tulo substancial que critica a interpretaç o de Copenhague da mec nica qu ntica, um tópico aparentemente distante da metodologia. Todavia, uma conseq ncia natural da insist ncia de Popper na objetividade do conhecimento cient fico é que ele deve procurar expurgar da teoria qu ntica o subjetivismo nela implantado por Heisenberg, em particular a interpretaç o subjetivista das probabilidades como medidas da ignor ncia e $\mathrm{n}$ o como freq ncias estat sticas. Popper, posteriormente, mudou sua opini o sobre a interpretaç o das probabilidades mec nico-qu nticas (sem enfraquecer a exig ncia de objetividade) e é conveniente adiar o sumário de suas cr ticas escola de Copenhague até que se diga algo sobre a interpretaç o da probabilidade como propens o, que ele prop s, pela primeira vez, nos anos 50 .

Professor de uma escola secundária quando esse maravilhoso livro estava sendo escrito, e ainda professor quando foi depois publicado em 1934, Popper começou a inquietar-se. Suas habilidades, em ci ncia e em matemática, n o estavam sendo utilizadas. Ele começou a se encontrar com outros membros do $\mathrm{C}$ rculo de Viena, especialmente com Carnap, seu principal defensor entre os empiristas lógicos, com $\mathrm{G}$ del e também com notáveis visitantes, em Viena, como Heisenberg em 1935 (1982(b), Prefácio, §III). Mas, por volta de 1935, Carnap e G del raramente participavam dos encontros do C rculo (Menger 1974) e Popper nunca foi convidado a tomar parte deles. Ele realmente falou em alguns dos encontros menos importantes e sua palestra sobre a aleatoriedade no mathematisches Colloquium de Menger, em 1935, despertou o interesse de Wald pela teoria da probabilidade. Passou a assistir a confer ncias internacionais, começando com o Vorkonferenz, em Praga, em 1934. Lá, encontrou Tarski, que pouco tempo depois, em Viena, explicou-lhe sua célebre 'concepç o sem ntica de verdade'. Essa foi uma ocasi o marcante para Popper, que já era um realista preocupado em esclarecer para si como 
reconciliar a idéia sensata de verdade com o senso comum; isto é, como especificar a correspond ncia entre enunciados verdadeiros e fatos. Desde ent o, defendeu as idéias de Tarski em numerosas ocasi es (nem sempre de um modo que agradasse a todos os demais defensores). A reabilitaç o (como ele a chamou posteriormente) da idéia sensata de verdade é de import ncia decisiva para a filosofia de Popper, já que ela envolve uma indispensável distinç o entre verdade e verdade justificada. Filósofos desde Plat o estiveram muito mais interessados no que pode ser justificado como verdadeiro - conclusivamente ou n o-do que no que é verdadeiro; a demanda por conhecimento, n o pela mera opini o, insistentemente proclama esta prefer ncia. No positivismo, a prefer ncia se torna aguda e a verdade é identificada com o que pode ser conhecido. Por oposiç o, uma conjectura genu na é claramente um enunciado que pensamos que pode ser verdadeiro sem que saibamos disso; $\mathrm{n}$ o apenas ele pode ser verdadeiro-e-n o-justificado como pode ser verdadeiro-en o-justificável.

Durante o ano acad mico de 1935-36, Popper se afastou de sua atividade de ensino, sem receber por ela, a fim de aceitar convites para falar no exterior (Hacohen 1996, p. 457): visitou Londres, Cambridge, Oxford, Bruxelas, Utrecht, e Copenhague; encontrou-se com Russell, Moore, Schr dinger, Hayek, Crowfoot, Woodger, Haldane, Bernal, Waddington, Oppenheim, Bohr e outros. Continuava a inquietar-se. Como vimos, há anos estava ciente de que quase n o havia chance de obter um cargo em uma universidade na Áustria; e seus amigos austr acos que ocuparam postos pouco fizeram em seu aux lio. No final de outubro de 1936, ele se candidatou, por sugest o de Woodger, no Universities Bureau of the British Empire, cadeira de professor de filosofia do Departamento de Educaç o e Filosofia, em Canterbury University College, Christchurch, uma das quatro unidades da Universidade Federal da Nova Zel ndia, nomeando Moore e Woodger como examinadores; e, em segundo lugar, a um cargo de conferencista, ao mesmo tempo oferecido. I.L.G. Sutherland de Wellington, que havia obtido seu doutorado em Glasgow, em 1923, com uma tese na área que chamamos atualmente de psicologia moral, um homem cinco anos mais velho do que Popper, foi indicado para a cadeira. Popper foi indicado para o cargo de conferencista. Deixando rapidamente Viena, no in cio de 1937, os Poppers se exilaram no outro lado do mundo ('a meio caminho para a Lua', como Hennie descreveu). 
$\mathrm{N}$ o se deve supor que Logik der Forschung foi o primeiro trabalho a rejeitar o indutivismo e defender o método hipotético. Liebig (1865) e Bernard (1865) haviam feito isso e Whewell (1840), embora acreditasse no poder da evid ncia emp rica para estabelecer a verdade de teorias cient ficas, deixou claro que as hipóteses s o essenciais se a ci ncia deve estabelecer alguma teoria (Medawar 1967). Popper referiu-se a Liebig, mas parece que nada sabia sobre Bernard e Whewell (ou Bachelard, que estava dizendo coisas similares na França). Contudo, a originalidade de Popper n o deve ser posta em dúvida. Ele foi o primeiro a salientar que o caráter hipotético de uma teoria jamais é mitigado, n o importando qu o numeroso e espl ndido é seu xito emp rico, e foi o primeiro a confrontar o indutivismo com uma alternativa metodológica sistemática, na qual a evid ncia n o cumpre um papel positivo na avaliaç o de teorias. De fato, n o foi tanto o indutivismo que ele destruiu, mas o justificacionismo, a vis o de que a racionalidade da ci ncia (e de outras atividades intelectuais) consiste na busca e obtenç o da verdade (parcial ou totalmente) justificada, em vez da verdade. Quase todos os cr ticos do falseacionismo erram nesse ponto, atribuindo-lhe exatamente aquelas aspiraç es justificacionistas que tanto se tentou descartar. Isso explica, em parte, por que Popper desconsiderou completamente muitas das objeç es que procuravam atacar suas posiç es. Ele nos encoraja a ver a ci ncia como uma atividade humana incauta, cujo extraordinário apego verdade sobre esse estranho e belo mundo n o é menos genu no por ser $\mathrm{t}$ o inseguro. Para citar uma de suas frases favoritas de Xenófanes (1963(a), §xv): 'tudo é apenas uma teia de conjecturas'.

\section{Na Nova Zel ndia, 1937-45}

Em 1937, o Departamento de Educaç o e Filosofia em Canterbury University College tinha dois catedráticos, um conferencista, um conferencista assistente em tempo integral, dois em tempo parcial e cerca de 80-100 estudantes [366.3]. Sutherland, o novo professor catedrático de filosofia, nessa época era realmente um antropólogo, um especialista em quest es de Maori, um homem que fora honrado pelo povo de Ngati Porou com o nome ancestral Paikea (Beaglehole et al. 1952). Popper era o 
único filósofo em atividade no departamento e ministrou todas as aulas de filosofia, que se restringiam a cursos que 'iam de Aristóteles a Bacon, mas sem usar o alfabeto lógico' (Godsiff 1972). Escrevendo a Carnap em 1943, ele se reportou a 'um extenso e exaustivo programa de aulas' de seis cursos e lamentou que sua 'avers o ao verbalismo vazio e ao escolasticismo da ampla maioria dos textos filosóficos estivesse aumentando proporcionalmente ao tempo de dedicaç o ao ensino de tais assuntos' [282.24]. Era de seu agrado

... um curso sobre os métodos cient ficos oferecido a pesquisadores (com discuss o acerca de seus problemas práticos de pesquisa, que levou a resultados práticos consideráveis; uma espécie de consultoria policl nica para qu micos agr colas etc.). Este curso foi muito interessante e bem-sucedido. É confortante descobrir que a filosofia pode ter algum uso prático!

Ele também contribuiu com cursos extramuros; por exemplo, com uma série de cursos de extens o universitária, em 1940, sobre religi o [366.20], e com um curso W.E.A., 'A ci ncia em construç o', para o qual ele produziu notas substanciais datilografadas [366.24]. Seu entusiasmo e sua vitalidade tornaram-se famosos para além de Christchurch: ele 'atuou como uma espécie de champanhe intelectual depois dos anos da depress o. ... o corpo docente e os estudantes lotavam suas confer ncias abertas sem ter em vista instruç o ou informaç o, mas esclarecimento e simples prazer intelectual de explorar o desconhecido com ele' (GARDNer et al. 1973, p. 263; citado em Bartley 1982, p. 253). A breve série de palestras que Popper foi convidado a apresentar em Dunedin, em 1944, também atraiu um grande número de pessoas (Eccles 1982, p. 221). Teve também o efeito notável de converter um crente ing nuo da induç o (como o próprio Eccles se descreveu) em um dos mais vigorosos defensores cient ficos do método de conjecturas e refutaç es.

Embora fosse promovido ao posto de professor associado [Senior Lecturer], t o logo o cargo fora institu do no in cio de 1941, Popper sentiuse pouco estimado e recompensado no Departamento em Canterbury. Havia disputas infindáveis com Sutherland, seu superior, que resultaram em um pedido formal de Popper ao reitor, em 1940, 'para investigar minha lealdade pela causa brit nica e minha compet ncia para lecionar, 
durante a guerra', que, ele suspeitava, tinha sido colocada em quest o. A este o reitor respondeu [366.5]: 'Eu n o quero deixar sombras de dúvida a respeito de minha bem fundada e firme convicç o em sua lealdade absoluta causa brit nica nessa guerra. ... Observei que sua influ ncia sobre seus estudantes tem um forte apelo ético, embasado na experi ncia pessoal, em defesa da causa brit nica.' Em 1944, aparentemente em conseq ncia de algum desacordo acerca da distribuiç o de gratificaç es para os examinadores, Popper escreveu ao diretor do Conselho: 'Por alguns anos, a cooperaç o no departamento de filosofia entre Sutherland e mim tornou-se cada vez mais dif cil, apesar de meu sério esforço para facilitar tal cooperaç o. A situaç o alcançou atualmente um tal estado que n o tenho outra opç o sen o pedir ao Conselho para rever a situaç o e esclarecer meus deveres e responsabilidades.' Sutherland, Popper afirmava, insinuou que ele estava negligenciando suas responsabilidades acad micas e descreveu seus protestos como 't picos do comportamento que nenhum brit nico ou neozeland s adotaria' [366.5]. (Isto pode ser uma fonte da alus o de Popper, muito depois, ao 'hábito brit nico de aceitar a adversidade sem se queixar’ (1963(a), §7).) O que estava por trás desta acusaç o fantasiosa de falta de cumprimento do dever era a tentativa de Popper, contra todas as dificuldades, de introduzir, por exemplo, uma tradiç o de pesquisa numa universidade onde tal coisa era desconhecida, uma universidade cuja 'direç o ... parecia considerar o tempo gasto em pesquisa como tempo subtra do da tarefa principal de lecionar' (SIMKIN 1993 , p. 183). Em toda a sua vida, Popper teve uma fort ssima avers o pol tica universitária e, provavelmente, foi sua realizaç o pol tica mais notável ter estabelecido na Universidade da Nova Zel ndia a idéia de que a pesquisa é um ingrediente indispensável do trabalho universitário (1945(e); GARDNER et al. 1973, p. 264s.).

Entre 1937 e 1943, Popper começou alguns estudos importantes sobre a axiomatizaç o da álgebra booleana e da teoria da probabilidade. Mas sua principal pesquisa, nesse per odo, foi em filosofia social e pol tica, um campo menos congenial de alguém que - apesar do entusiasmo juve-nil - n o era, 'nem por inclinaç o nem por formaç o, um estudioso da sociedade ou da pol tica' [253.3]. Horrorizado com a tragédia que estava se alastrando pela Europa e n o sendo aceito para o serviço militar da Nova Zel ndia (GARDNER et al. 1973, p. 262), ele estabeleceu para si, como trabalho de guerra, a tarefa de expor as origens intelectuais do tota- 
litarismo - $\mathrm{n}$ o somente do facismo mas também do comunismo, que ele esperava vir a ser um problema maior se a guerra contra Hitler fosse vencida. Em certos aspectos, esse trabalho era a continuaç o da cr tica do marxismo iniciado em 1919. No centro do alvo estava a doutrina que ele nomeou de historicismo, a doutrina que afirma serem os grandes rumos da história humana, se n o os seus detalhes, governados por leis históricas ou leis do destino. A criaç o historicista de mitos contamina a maioria do pensamento totalitário, de Plat o a Hegel e Marx, a Hitler e Stalin, e tem toda uma nefasta influ ncia intelectual sobre a humanidade e sobre a tentativa de o homem construir para si uma vida melhor. As cr ticas mais anal ticas e metodológicas do historicismo est o em The poverty of historicism, originalmente publicado em tr s partes em Economica, em 1944-45, e posteriormente desenvolvido e publicado na forma de livro como $1957(\mathrm{~g})$; aquelas que est o mais estreitamente relacionadas com quest es metaf sicas, éticas e pol ticas est o contidas em The open society and its enemies 1945(b)(c), em cujo prefácio Popper descreve como 'uma introduç o cr tica filosofia pol tica e da história e um exame de alguns princ pios de reconstruç o social'. Apropriadamente para um livro que uma vez foi chamado 'Uma filosofia social para todos', The open society está escrito com uma clareza transcendente. Mas Popper sabiamente adverte que, '[e]mbora o livro apenas pressuponha que o leitor tenha uma mente aberta, sua intenç o n o é tanto popularizar as quest es tratadas mas solucioná-las' (loc.cit.). O texto do livro está repleto de argumentos; as notas abundantes, sobre um amplo dom nio de tópicos periféricos, aumentam ainda mais a profus o de pensamentos.

Este n o é o lugar para expor as concepç es sociais e pol ticas de Popper (Simkin 1993, Parte II; Shearmur 1996) ou as cr ticas que sustentou contra Plat o e Marx. Mas pode-se dizer que essas concepç es n o s o, de modo algum, independentes de suas contribuiç es anteriores teoria do conhecimento. Popper trouxe ao estudo da sociedade o mesmo antiautoritarismo que trouxera ao estudo da ci ncia; em particular, a crença de que a demanda razoável de controle $\mathrm{n}$ o deve ser confundida com a demanda irrazoável de segurança. Insiste em que, como os erros s o inevitáveis, devemos dirigir nossas energias mais para sua cura do que para sua prevenç o e que, portanto, deve ser a reforma social monitorada e feita aos poucos, em vez de ser monol tica e utópica. Popper, o defensor do pensamento revolucionário em ci ncia - já que as novas teorias audazes 
s o facilmente descartadas, caso sejam falsas -, é o mesmo pensador que se op e atividade revolucionária na sociedade. Deve-se notar que o antiautoritarismo n o implica, como alguns recentes pensadores e pol ticos t m imaginado, que a intervenç o do Estado deva ser totalmente evitada. De fato, Popper deixa claro que o Estado deve estar sempre pronto a intervir, ainda que só para impedir que outros intervenham. Um paralelo significativo é traçado (1945(c), cap tulo 24, nota 7) entre esse paradoxo da liberdade (a liberdade irrestrita subverte a liberdade) e outros paradoxos da soberania, tais como o paradoxo da regra da maioria (o povo pode votar em um tirano) e o antigo paradoxo do mentiroso ('Este enunciado é falso'). Como se nota a seguir, um outro paralelo significativo entre os paradoxos da soberania e os problemas fundamentais da teoria do conhecimento seria traçado posteriormente.

Embora as principais teses de The open society estejam inevitavelmente relacionadas com o pensamento das pessoas em geral, há um ou dois temas abordados que podem ter um interesse particular para cientistas de ambos os sexos. Há, por exemplo, a explicaç o da objetividade cient fica em termos de intersubjetividade (cap tulo 23), que reconhece que os cientistas tomados individualmente n o s o objetivos, mas sustenta que, no ambiente de uma discuss o cr tica livre, somente poss vel em uma sociedade aberta, a subjetividade, no que ela é perigosa, pode ser largamente neutralizada. Os pré-requisitos sociais e institucionais da ci ncia s o enfatizados - a ci ncia também deve ser uma sociedade aberta -, mas a doutrina determinista, proposta por Mannheim e, uma vez mais, imerecidamente popular, segundo a qual as teorias cient ficas n o s o mais do que produtos sociais, é rejeitada. Há uma conjectura intrigante (adicionada em 1952(a) nota 9 do cap tulo 6), que afirma que a identidade aproximada $\sqrt{2}+\sqrt{3} \approx \pi$ pode ter encorajado Plat o a pensar que todos os números irracionais s o simples funç es de $\sqrt{2}$ e $\sqrt{3}$ e ter reforçado sua opini o de que os sólidos regulares plat nicos (nos quais somente esses irracionais aparecem) guardam a chave do entendimento da natureza. Há também uma importante, ainda que resumida, cr tica do ideal de uma educaç o liberal. Popper escreveu (cap tulo 11, nota 6)

... em nossos dias, $\mathrm{n}$ o pode ser considerado educado quem $\mathrm{n}$ o tem interesse pela ci ncia.... Quem nem sequer tenta adquirir uma compreens o desse movimento isola-se do mais notável 


\begin{abstract}
desenvolvimento da história dos interesses humanos. ... a educaç o literária [n o só] falha em educar o estudante ... em uma compreens o do maior movimento espiritual de seu próprio tempo, como também falha muitas vezes ao educá-lo na honestidade intelectual. Somente quando o estudante aprende pela experi ncia quanto é fácil errar e dif cil realizar um pequeno avanço no campo do conhecimento, só ent o ele poderá obter o senso dos padr es de honestidade intelectual, o respeito verdade, o desdém pelo autoritarismo e pela presunç o.
\end{abstract}

Citando a concepç o de T.H. Huxley de que uma educaç o liberal, longe de incutir 'o poder de ver as coisas como elas s o sem considerar a autoridade', faz o melhor para suprimi-lo, Popper continuou:

\begin{abstract}
Admito que, infelizmente, isso é verdade com respeito a muitos cursos cient ficos, que ainda s o tratados por muitos professores como se fossem 'um corpo de conhecimento', no sentido da express o antiga. Espero, porém, que essa idéia um dia desapareça, pois a ci ncia pode ser ensinada como uma parte fascinante da história humana - como um desenvolvimento de hipóteses audaciosas a serem desenvolvidas rapidamente e controladas pela experimentaç o e p.ela or tica. Ensinar desse modo ... poderia tornar-se a base de uma nova educaç o liberal universitária, cuja meta, onde n o puder produzir especialistas, será pelo menos formar bomens que possam distinguir um charlat o de um especialista.
\end{abstract}

É triste que mesmo esses modestos objetivos ainda estejam muito longe de ser alcançados. O culto do especialista está crescendo, assim como o culto do charlat o. Poucos estudantes de humanidades aprendem a pensar a ci ncia como uma estimulante aventura intelectual, que exige coragem e humildade. Com os estudantes de ci ncia, a situaç o é normalmente ainda pior (BONDI 1992).

O primeiro volume de The open society foi finalizado em outubro de 1942 e o segundo, em fevereiro de 1943. Cada um foi várias vezes reescrito e datilografado por Hennie (Gombrich 1995). Encontrar um editor n o foi menos dif cil. Uma cópia entregue aos cuidados de um amigo norteamericano ficou mofando em sua escrivaninha. O livro parecia ser muito desrespeitoso com Aristóteles para que fosse apresentado a um editor. (Aristóteles tem uma import ncia relativamente pequena no livro. Posteriormente, Popper reconheceu injusta sua abordagem.) Finalmente, 
Popper entrou em contato com Ernst Gombrich, que conhecera em Londres antes de partir para a Nova Zel ndia. Gombrich incumbiu-se de apresentar o livro e, com a assist ncia de F.A. von Hayek, conquistou o interesse de Herbert Read, no George Routledge \& Sons, embora tivesse sido rejeitado pela Cambridge University Press por ser desrespeitoso com Plat o. Mais ou menos na mesma época, Hayek, em cujo seminário, anos antes, Popper lera uma vers o prévia de The poverty of historicism, articulou para levá-lo London School of Economics (LSE). O último ocupante da cadeira de Lógica e Método Cient fico, que dividia a metade do tempo com a University College, aposentou-se em 1941 depois de 35 anos de serviço (Dahrendorf 1995, p. 205, 369). Hayek e Ginsberg concordavam acerca da continuidade do ensino de certos assuntos, mas, enquanto Ginsberg pensava que a quest o n o era urgente, Hayek tinha um candidato na manga; a cadeira de meio per odo, ele prop s, deveria ser convertida em uma de tempo integral, para ser ocupada n o por um jovem brilhante mas por um lógico e filósofo maduro e experiente [368.1]. Hayek prevaleceu. Na primavera de 1944, Popper recebera um contrato da Routledge para The open society (Gombrich 1995, p. 11; Simkin 1993, p. 187); doze meses depois, ele foi indicado para ser professor na LSE. The open society deve ter sido um dos melhores investimentos da Routledge, pois o livro recebeu seis ediç es e foi impresso durante cinq enta anos. A LSE também fez bem. O depoimento que Russell escreveu em 1936 n o exagerou em sua descriç o de Popper como 'um homem de grande habilidade, que qualquer universidade gostaria de ter em seu corpo docente' ([406.4]; a passagem citada por GratTAN-GuINNESS 1992, p. 5).

A vida dos Poppers na Nova Zel ndia parece ter sido austera, pouco se afastando do ensino e da pesquisa. Decerto, praticavam montanhismo e esqui nos Alpes do Sul e ele conta, no ap ndice *x de 1959(a), que, em 1938 ou 1939, eles foram escavar ossos de moas no p ntano de Pyramid Valley, cerca de 50 milhas a noroeste de Christchurch. Depois da Anschluss, eles organizaram um comit para ajudar os refugiados austr acos a obterem visto de entrada na Nova Zel ndia. De seu salário, sa am elevados pagamentos da hipoteca de sua casa de madeira em Cashmere Hill (onde Popper aproveitava a oportunidade para empregar suas habilidades de carpintaria), grandes import ncias de um seguro de vida e alguma ajuda (via Cruz Vermelha) para sua irm Annie na Su ça. Seus principais luxos parecem ter sido sorvetes e milkshakes. Mas a austeridade e a sim- 
plicidade eram o que os sociais-democratas em Viena sempre prescreveram e - exceto pela hostilidade departamental - parece que os Poppers estavam contentes. A redaç o de The open society os deixou exaustos. Mas, mesmo depois da indicaç o para a LSE ter sido confirmada, seus problemas na Nova Zel ndia n o foram totalmente superados. Popper relutou em deixar seu cargo em Canterbury (em virtude do qual lhes foi permitido viverem na Nova Zel ndia), uma vez que eles estavam sem pátria e o governo brit nico havia garantido visto por apenas doze meses. Embora quisessem voltar Europa, n o podiam abrir $\mathrm{m}$ o do direito de viverem em um pa s livre. Mas a preocupaç o era desnecessária. Em 25 de outubro de 1945, ele obteve um afastamento para o ano acad mico de 1946 e, em 1 de novembro, ele e Hennie naturalizaram-se brit nicos [325.27]. (A cidadania só foi obtida em 1949.) Ele finalmente renunciou a seu cargo na Nova Zel ndia em 18 de junho de 1946 [366.4].

\section{Na LSE, 1946-59}

Popper chegou LSE, em janeiro de 1946, para ser novamente o único filósofo em uma instituiç o. (Mas n o por muito tempo: J.O. Wisdom juntou-se ao departamento em 1948.) Contudo, havia outros filósofos por perto e ele rapidamente foi bem acolhido em Londres e regi o. Pela primeira vez em dez anos, assistiu a confer ncias e encontros filosóficos; tanto assim que foi conferencista convidado na Joint Session of the Aristotelian Society and the Mind Association (o encontro anual de filósofos brit nicos), em 1946, 1948 e 1953. Apesar da grande amabilidade que havia demonstrado e do grande respeito que tinha pela capacidade de alguns filósofos que conhecera [290.6], ele encontrou na Gr -Bretanha uma atmosfera profissional desconfortavelmente alienada. Era um pa s que por seis anos esteve em combate numa guerra sangrenta pela sobreviv ncia e seus principais filósofos perdiam tempo com quest es como a de se outras mentes existem ou se um objeto f sico continua a existir quando ninguém o está observando. Simpatizou apenas com Russell e alguns poucos outros, embora estivesse desapontado com o fato de Russell, em seu Human knowledge (1948), retornar a algo como o indutivismo de J.S. Mill. (Russell possu a uma cópia de Logik der Forschung, mas as páginas 
quase n o foram separadas. Ver Grattan-Guinness 1992, p. 8.) De fato, Popper nunca chegou a um acordo com a filosofia acad mica na $\mathrm{Gr}$ Bretanha (ou em outro lugar). Ele tinha profunda antipatia pela filosofia ling stica, em voga durante sua chegada, em 1946, e que continuou a dominar as discuss es pelo menos até o final dos anos 60, algumas vezes comparando limpeza dos óculos as preocupaç es filosóficas com as sutilezas da linguagem - uma tarefa necessária, sem dúvida, mas somente acessória ao objetivo dos óculos (1971(m), p. 138). A cr tica ácida de Gellner em Words and things (1959) estava 'certa em quase todos os pontos' [386.15]. Os problemas, sustentava Popper, n o podem ser solucionados pela análise da linguagem - 'problemas somente podem ser resolvidos com a ajuda de novas idéias' (1976(g), §7). Ele tinha menos respeito ainda pelas reencarnaç es levianas do marxismo, que constitu ram muito da moda filosófica a partir dos anos 70 (embora ele tivesse considerável simpatia pela seriedade do próprio marxismo). Sempre pol mico e fora de moda, ele seguiu Kraft (1957; ver 1962(f), p. 11), que citava, com aprovaç o, von Hofmannsthal: 'A filosofia deve ser um juiz de seu tempo; as coisas $\mathrm{v}$ o mal quando ela se torna uma express $o$ do esp rito de seu tempo' (1967(e); 1994(y), p. 159).

$\mathrm{Na}$ Nova Zel ndia, n o havia nenhum outro filósofo profissional em um raio de 200 milhas de Christchurch, e Popper fez mais amigos fora dos c rculos filosóficos. Embora fosse errado sugerir que ele n o manteve um relacionamento decentemente cordial, pelo menos por alguns anos, com os colegas brit nicos de filosofia, esta sua predileç o persistiu até o fim de sua vida: ele possu a poucos amigos filósofos, além de seus próprios alunos. Como em Viena antes da guerra, tinha a reputaç o de ser brilhantemente arguto, irritadiço, sendo dif cil dele discordar. Ele certamente tinha dificuldades em levar a pior, mas isto pode ser atribu do tanto ao seu preparo - ele normalmente já tinha considerado as objeç es de seus cr ticos e encontrado um modo de respond -las - quanto sua combatividade. Quando lhe era dito algo sobre o qual ele n o havia pensado, ele era todo ouvidos (uma express o usada na quarta fala do diálogo no cap tulo 14 de 1963(a), talvez em um momento de inconsciente paródia de si mesmo). Dentre seus novos conhecidos na Gr -Bretanha, Peter Medawar, com quem se encontrou no Theoretical Biology Club de Woodger em $1946\left(1986\left(z_{3}\right)\right)$, foi de import ncia especial e quase imediata. Eles rapidamente se tornaram amigos, cada um se estimulou e se interessou 
pelas idéias e problemas do outro, e exerceram, um sobre o outro, forte e positiva influ ncia; por exemplo, encontramos Medawar, em junho de 1947, convidando Popper para ir a Oxford falar para seu grupo acerca do teorema de $G$ del, dos paradoxos de Zen o e da teoria da quantificaç o, um programa altamente extenuante para uma única noite [325.25]. Eles eram membros da Sociedade de Metalógica, que, entre 1949 e 1953, reunia-se mensalmente sob os ausp cios de A.J. Ayer (Crawshay-Williams 1970, p. 60). Medawar documentou em vários lugares (1967, 1986 e em outros também) sua d vida para com Popper, cujas recomendaç es metodológicas ele adotou entusiasticamente e colocou em prática t o completamente como Eccles; e quando ele foi eleito membro da Royal Society, em março de 1949, escreveu [325.26], reconhecendo sua d vida, que Popper merecia uma 'parte' do t tulo. (Em outubro de 1960, ele novamente atribuiu a Popper uma parte do crédito ganho pelo seu pr mio Nobel [325.25].) Esta parte acabou sendo paga com o que deve ter sido seu notável interesse.

Inicialmente, Popper teve de dedicar-se muito menos doc ncia do que na Nova Zel ndia - apenas \#390 L gica e \#391 M todo cient ficos o anunciados no programa da LSE de 1945-46 [389.6] - mas, no final de 1947, ele pesarosamente lecionava oito horas por semana [282.24]. O efeito fenomenal obtido em Christchurch repetiu-se durante todos os anos de LSE. Lecionando com um m nimo de notas, Popper atraiu grandes audi ncias, compostas tanto por colegas e visitantes como por estudantes universitários e pesquisadores. Ele n o seguia programa de curso algum e freq entemente falava sobre algum tópico que envolvesse seu interesse no momento. Os estudantes de $M$ todo cient fico sem familiaridade com $\mathrm{f}$ sica eram mais do que uma vez convidados a combater a interpretaç o ortodoxa da mec nica qu ntica. Seu célebre seminário, em que amigos e adversários expunham as idéias a seu ataque incessante, n o era uma experi ncia para pessoas pouco corajosas, e muitos o consideravam prepotente e opressivo. Os tolos eram tolerados, nem sempre de bom grado, mas n o os convencidos e fanfarr es. Um problema claro e uma tese provocativa, enunciados em termos simples, sem jarg es ou tecnicidades, constitu am o que todo falante era aconselhado a trazer consigo. Mas n o estava dito de qual direç o a cr tica viria. Tudo o que se garantia é que logo viria.

Em 1947-48, Popper publicou sete artigos sobre lógica, frutos do trabalho intenso e solitário na Nova Zel ndia. Nesses artigos, em que 
redescobriu boa parte do sistema de deduç o natural de Gentzen, ele esperava solucionar um problema em aberto na discuss o de Tarski sobre a conseq ncia lógica (1936, p. 420), a saber, clarificar a distinç o entre constantes lógicas (tais como n o e todo) e constantes extralógicas (tais como c o e lobo); e, por meio disso, mostrar que a validade das regras da lógica pode ser reduzida a definiç es (1947(b)). Há erros na segunda parte do projeto, como os resenhistas rapidamente identificaram; mas os artigos 'cont m uma proposta detalhada e bem fundamentada' (SchroederHeister 1984, p. 80) para caracterizar as constantes lógicas. Parece que Tarski, cujo ju zo Popper respeitava imensamente, n o estava muito interessado nesse trabalho quando lhe foi mostrado e esta reaç o, tanto quanto os enganos cometidos (Popper sempre foi muito sens vel a erros que n o percebia por si), desencorajou outros esforços.

The open society e outros trabalhos foram, com sucesso, apresentados na Universidade de Londres, em 1948, como uma tese para o grau de D.Lit.. Sua habilitaç o para a cátedra preocupou Popper por algum tempo (Medawar 1986, p. 113-115), mas a fragmentaç o de seu curr culo em lógica e método cient fico, nessa época, tornou dif cil para a LSE apresentar raz es universidade para o estabelecimento ou restabelecimento de uma cadeira. Se a m e de Hennie, que ainda estava na Áustria, n o tivesse ficado seriamente doente, os Poppers poderiam muito bem ter sido persuadidos a retornar definitivamente Nova Zel ndia, para a cátedra vaga, em Otago, com a qual Eccles persuasivamente tentou atra -lo [290.7]. (A única ocasi o em que eles voltaram Nova Zel ndia foi em 1973, como visitantes das Universidades de Otago e de Canterbury.) O problema foi finalmente resolvido com a promoç o de Popper cátedra especial para ele, em 1 de janeiro de 1949. Depois deste m s, chegou uma carta inesperada do Professor Donald Williams, Chefe do Departamento de Filosofia de Harvard, perguntando se Popper 'aceitaria um convite para apresentar as confer ncias William James', em 1949-50 [304.25]. Popper disse que 'pensou ter ocorrido algum engano' (1976(g), §28), e que ele estava sendo confundido com Josef Popper-Lynkeus, um consagrado filósofo e sociólogo, também de Kolin, que pertencera aos Monistas, o c rculo de Mach e Ostwald. Mas isto é dif cil de se acreditar; por um lado, Popper-Lynkeus morrera 30 anos antes, aproximadamente; por outro, a primeira carta de Williams menciona explicitamente The open society. Uma gratificaç o de $\$ 6.000$ foi oferecida por oito ou dez confer ncias semanais 
e uma série de seminários paralelos. Ele apresentou as confer ncias intituladas The study of nature and of society - tal como planejado, ao que tudo indica, somente a partir de notas. Os seminários foram sobre The structure of experience (um t tulo um tanto estranho). Embora uma das condiç es da série de confer ncias, $\mathrm{n}$ o mencionada por Harvard em tempo hábil, fosse que o conferencista deixaria uma cópia manuscrita de suas exposiç es na biblioteca da universidade, Popper nunca a cumpriu, nem sequer produziu o trabalho obrigatório para a publicaç o.

Mas ele nunca se acomodava. A década de 50 foi extraordinariamente produtiva. Conjectures and refutations 1963(a) reúne artigos importantes da época sobre diversos problemas em filosofia da ci ncia, lógica, relaç o corpo / mente, metaf sica, filosofia social e sobre os filósofos pré-socráticos. Um destes artigos (cap tulo 6) mostra em que medida as cr ticas de Mach ao espaço, tempo e movimento absolutos foram antecipadas por Berkeley no De motu (1721). Popper distanciou-se da tend ncia instrumentalista dessas cr ticas e também do essencialismo - na explicaç o de Cotes para a gravidade, por exemplo - qual elas se dirigiam; e argumentou (cap tulo 3) em favor de uma posiç o intermediária acerca da ci ncia, como a busca de explicaç es mais profundas, porém nunca últimas ou definitivas. Começando com 1954(d), havia sete notas, nos cinco anos de discuss o com Carnap e Bar-Hillel, sobre a identificaç o indutivista da probabilidade com o grau de corroboraç o. Em um artigo em conjunto (1954), esses autores aceitaram a doutrina de Popper da relaç o inversa entre probabilidade e conteúdo, mas separadamente resistiram conclus o de que a investigaç o emp rica $\mathrm{n}$ o se destina a tornar nossas teorias mais prováveis. 1956(b) deu in cio a uma série de comentários, a maioria em Nature, sobre a flecha do tempo e a interpretaç o correta da segunda lei da termodin mica, tópicos sobre os quais ele tinha altercaç es com Schr dinger. Por insist ncia de Hennie - ela teve de chorar toda a noite para persuadi-lo -, Popper também empreendeu (com ajuda de outras pessoas) a traduç o para a 1 ngua inglesa de 1934(b), um projeto que foi implantado já em 1937, mas logo parou por falta de apoio financeiro (Godsiff 1972; WoOdger finalizou uma traduç o em 1946 [12.13], mas jamais a usou). Embora o resultado, The logic of scientific discovery 1959(a), contivesse muito material adicional, reunido em novas notas e novos ap ndices, muito foi omitido. Conforme a traduç o prosseguia, tornou-se claro que os frutos de 20 anos de reflex o, especialmente sobre 
a interpretaç o da probabilidade e quest es correlatas, seriam suficientes para completar um outro livro; e, assim, outro livro foi concebido e escrito, sob o t tulo de Postscript: after twenty years. Projetado para 1954, ele passou a tomar forma no final de 1957. Mas, por várias raz es, incluindo um perfeccionismo exagerado e uma grave doença, a correç o das provas deste volume suplementar estava ainda inacabada em 1962, quando ficou de lado durante outros 20 anos. Finalmente foi publicado em tr s volumes como 1983(b) e 1982(a)(b), contendo um segundo acréscimo de novo material em uma grande aglutinaç o de prefácios, introduç es e adendos.

Popper viajou muito. Encorajado por Hayek, começou já no ano de 1948 a participar dos encontros de The Austrian College Society, em Albach (Tirol), um grupo fundado em grande parte pelos primeiros membros da resist ncia para cuidar dos valores democráticos na Áustria do pós-guerra. Foi convidado a passar o ano acad mico de 1956-57 no Instituto de Estudos Avançados em Ci ncias do Comportamento, em Stanford. Esta visita quase foi impedida pela solicitaç o ing nua de um visto ao consulado dos Estados Unidos; tendo originalmente escrito que alguns amigos de sua juventude 'depois tornaram-se comunistas', Popper ent o se explicou dizendo que eles 'se denominavam comunistas'. Disseram-lhe que esta associaç o teria de ser comunicada a Washington e enquanto isso ele deveria obter, de cidad os proeminentes e ntegros, cerca de 20 declaraç es de que ele $\mathrm{n}$ o era um comunista. Seus amigos o ajudaram, escrevendo cartas, indignados com o governo norte-americano por ter imaginado que o autor de The open society tivesse alguma simpatia pelo comunismo [407.23]. Foi somente a intervenç o de um alto diplomata aposentado que $\mathrm{p}$ s fim perda de tempo dessa investigaç o.

É quase imposs vel fazer justiça riqueza das idéias surpreendentemente novas que Popper apresentou entre 1950 e 1959 (ele continuou a trabalhar com muitas delas por muitos anos). As principais contribuiç es do Postscript ser o descritas na próxima seç o. Antes, é necessário dizer algo sobre suas notáveis axiomatizaç es 'aut nomas' da teoria elementar da probabilidade.

Popper publicara sua primeira axiomatizaç o da teoria da probabilidade (um tanto tosca) já em 1938(a). Nada mais foi publicado até 1955(b), mas nesse per odo sua posiç o quanto ao assunto tomou um curso inesperado. Sem conhecer a axiomatizaç o de Kolmogorov de 1933, 
hoje quase can nica, ele se interessou, originalmente, apenas em apresentar uma axiomatizaç o abstrata para a funç o unária $p(y)$. (Em termos dessa funç o, a probabilidade condicional $p(x \mid z)$ é geralmente definida como o cociente $p(x z) / p(z)$, para $p(z)$ positivo; aqui, a concatenaç o representa a interseç o ou conjunç o.) Depois, afortunadamente enganado pelo fato de que, na interpretaç o propensional (a ser discutida abaixo), as probabilidades sempre s o relativas s condiç es $\mathrm{f}$ sicas do ambiente, ele decidiu adotar a funç o binária $p(x \mid z)$ como primitiva. Chamemos $x$ e $z$ [probabilisticamente] indistingu veis, se, para todo $y$, as probabilidades $p(x \mid y)$ e $p(z \mid y)$ s o iguais; simbolicamente, $x \sim z$. Em um certo estágio, Popper notou que, supondo $(x z) y \sim(x y)(z y)$, podemos facilmente derivar a propriedade distributiva $(x \vee z) y \sim x y \vee z y$ (aqui, $\vee$ representa a uni o ou disjunç o) a partir das leis (gerais) de adiç o e multiplicaç o

$$
\begin{aligned}
p(x \mid y)+p(z \mid y) & =p(x z \mid y)+p(x \vee z \mid y), \\
p(x z \mid y) & =p(x \mid z y) p(z \mid y) .
\end{aligned}
$$

(Esta derivaç o é o ponto central de uma das cr ticas em 1968(q) tese de Birkhoff \& von Neumann segundo a qual a mec nica qu ntica, que sem dúvida é, em algum sentido, uma teoria probabil stica, requer uma lógica n o-distributiva.) Ora, a identidade dos termos $(x z) y$ e $(x y)(z y)$ se segue a partir das leis familiares de reticulado: idempot ncia $(y y=y)$, comutaç o $(x z=z x)$ e associaç o $(x(y z)=(x y) z)$. Popper trabalhara, na Nova Zel ndia, com a axiomatizaç o da álgebra booleana (e sobre Boole [4.12]) e parece que foi levado a pensar que os axiomas adequados para o funtor $p$ poderiam também estabelecer a indistinguibilidade desses termos e, portanto, a lei distributiva probabil stica $p((x \vee z) y \mid w)=p((x y \vee z y \mid w)$. $\mathrm{E}$ assim a provou. Um dos vários sistemas axiomáticos elegantes que realiza esta tarefa é o seguinte (1994(e), ap ndice *V):

$$
\begin{array}{ll}
\text { A1 } & \exists x \exists z p(x \mid x) \neq p(x \mid z) \\
\text { A2 } & \forall p(y \mid y) \leq p(x \mid z) \leq p(z \mid x)] \Rightarrow \forall y[p(y \mid x) \leq p(y \mid z)] \\
\text { A3 } & p(x \mid x) \leq p(z \mid z) \\
\text { B1 } & p(x z \mid y) \leq p(x \mid y) \\
\text { B2 } & p(x z \mid y)=p(x \mid z y) p(z \mid y) \\
\text { C } & p(x \mid x) \neq p(y \mid z) \Rightarrow p(x \mid x)=p(x \mid z)+p\left(x^{\prime} \mid z\right)
\end{array}
$$


$\mathrm{O}$ acento na express o do axioma $\mathrm{C}$ representa uma operaç o unária que revela ter todas as propriedades do complemento. $\mathrm{O}$ sinal $\vee$ para uni o é introduzido pela definiç o: $x \vee z=\left(x^{\prime} z^{\prime}\right)^{\prime}$. Há, como em todos os sistemas axiomáticos de Popper para a probabilidade condicional, alguns aspectos incomuns. Em primeiro lugar, $p(x \mid z)$ é definido para todo $z$, incluindo o elemento contraditório $y y^{\prime}$; de fato, $p\left(x \mid y y^{\prime}\right)=1$. Em segundo lugar, os limites usuais da funç o $p \mathrm{n}$ o aparecem explicitamente; $0 \leq p(x \mid z) \leq 1$ é um teorema. E o que é mais importante, $\mathrm{n}$ o se faz nenhuma suposiç o concernente ao dom nio de elementos $x, y, z, \ldots$, nem que é uma álgebra booleana nem que é um reticulado; nenhuma das identidades definidas é assumida pela operaç o de concatenaç o e nenhuma identidade definida para o complemento é assumida por'. É esta aus ncia de quaisquer suposiç es puramente algébricas que a descriç o 'aut noma' pretende frisar. Todavia, o dom nio é redut vel a uma álgebra booleana, no sentido de que $s=t$ é uma identidade da álgebra booleana se e somente se a indistinguibilidade probabil stica de $s$ e $t$ pode ser derivada no interior do sistema. Isto estabelece um resultado que anteriormente tinha sido mero boato: a saber, que a teoria da probabilidade é uma generalizaç o genu na da lógica proposicional clássica, n o apenas uma extens o dela (no sentido de que, como aqui formulada, é somente uma extens o de alguma teoria dos números reais). De fato, a relaç o de dedutibilidade $z \vdash x$ pode ser definida de diversos modos; por exemplo, pela relaç o $z \sim x z$ ou pela identidade $p\left(x \mid z x^{\prime}\right)=1$.

Um sistema axiomático, diferente do sistema acima apenas em aspectos secundários, foi detalhado e comparado com diversas alternativas em dois novos ap ndices, $*_{\text {iv e }} *_{\mathrm{v}}$, de 1959(a). Popper arriscou a opini o de que ele 'dificilmente pode ser mais simplificado' (op.cit., ap ndice $*_{\mathrm{ii}}$, nota $*_{\mathrm{i}}$ ), mas jamais deixou de trabalhar nos refinamentos, aperfeiçoamentos e variaç es dele. Algumas das provas cruciais, na apresentaç o original de Popper, foram de fato decisivamente simplificadas em 1994(x). Leblanc (1989) fornece um painel comparativo com outro trabalho, incluindo as axiomatizaç es contempor neas publicadas por Rényi (1955), que também toma como primitivo o funtor de probabilidade condicional. Embora os sistemas de Popper claramente contribuam mais para a álgebra abstrata do que para a filosofia, eles também s o uma realizaç o filosófica notável, revelando conex es ntimas e sutis entre lógica e teoria da probabilidade. Popper explicou sua investida em um tal 
exerc cio técnico pela raz o de que somente se as propriedades definitivas da probabilidade fossem estabelecidas, poder amos ter esperança de avaliar a tese indutivista de que a probabilidade condicional $p(b \mid e)$ de uma hipótese $b$ dada a evid ncia $e$ é id ntica a seu grau de corroboraç o. Podese questionar se seu objetivo subjacente - aniquilar essa tese - foi obtido. De qualquer modo, é curioso que, ao apresentar os produtos finais de sua longa investigaç o, Popper os depreciasse como 'um tanto técnico - muito para o meu gosto, pelo menos' (1959(a), prefácio aos novos ap ndices) -, uma vez que o prazer com que trabalhava neles e a import ncia que lhes atribu a eram bem conhecidos. Ele, de modo correto, sempre questionou o culto da precis o por si mesma, mas esses belos sistemas axiomáticos n o s o um exemplo de precis o por si mesma.

No in cio dos anos 50, os Poppers compraram Fallowfield, a casa em Penn (Buckinghamshire) em que morariam por quase 35 anos. (Anteriormente, eles viveram em East Barnet [293.7].) Situada no subúrbio de Londres, quase no limite do raio de trinta milhas exigidas pela Universidade de Londres (BARTLEY 1982, p. 254), dificilmente acess vel por transporte público, Penn ainda era uma vila e Fallowfield, uma casa relativamente pequena, com um grande jardim em uma rua particular. Assim começou um processo de distanciamento da vida metropolitana que, no final da década, levou-o a hábitos quase erem ticos. Sempre incomodado com as salas cheias de fumaça, raramente Popper ia aos encontros de comit s e conselhos na LSE. As contrataç es de Joseph Agassi em 1957, de J.W.N. Watkins (que se transferiu do Departamento de Ci ncia Pol tica) em 1958, de W.W. Bartley III e Imre Lakatos em 1960 (quando Agassi partiu) e de Alan Musgrave em 1964 notadamente ajudaram a reduzir sua carga de trabalho (alguns anos depois, ele só apresentava uma confer ncia e um seminário por semana). Desobrigou-se também de muitas responsabilidades administrativas, assumidas principalmente por Agassi e Watkins. Do in cio dos anos 50 até o in cio dos 80, a Fundaç o Nuffield e outras mantiveram um assistente de pesquisa para Popper, um luxo singular para um filósofo, e uma das principais tarefas do assistente, em contato diário por telefone, era procurar livros e periódicos; uma tarefa considerável, uma vez que os interesses de Popper em ci ncia natural eram apenas precariamente servidos pela Biblioteca Brit nica de $\mathrm{Ci}$ ncia Pol tica e Econ mica (de fato, em um ano, o assistente foi a fonte de $50 \%$ dos pedidos da biblioteca para o Serviço de Empréstimo Interbibliote- 
cas). Popper freq entemente conseguia restringir sua presença na LSE a um dia por semana.

Com a publicaç o de The logic of scientific discovery 1959(a), Logik der Forschung estava dispon vel em traduç o inglesa. O Postscript foi planejado em seguida, $t$ o logo as provas foram corrigidas para incorporar as extensas sugest es de um novo cr tico, W.W. Bartley, que chegara LSE em 1958. Mas a saúde de Popper, sempre uma preocupaç o para ele, piorou seriamente em 1960, quando a sua vis o começou a falhar. Retornando apreensivamente a Viena, ele se submeteu a cirurgias para tratar do descolamento de retina nos dois olhos. As operaç es foram bemsucedidas, mas o trabalho com as provas do Postscript foi deixado de lado e, por volta de 1962, abandonado. O texto revisado foi novamente datilografado em 1969, porém, mais uma vez, foi posto de lado. Várias partes foram extra das em sua totalidade e publicadas independentemente; no in cio dos anos 80, época em que o livro foi, enfim, publicado, quase havia se tornado um documento histórico. É conveniente atentarmos para seu conteúdo e retomar, na seç o seguinte, a história da carreira de Popper na LSE. Nenhum significado profundo, como um momento de ruptura, está vinculado ao ano de 1960.

\section{O Postscript}

O fio condutor do Postscript, em sua vers o original sem suplementos, é a interpretaç o propensional da probabilidade, com a qual Popper buscou superar alguns problemas importantes enfrentados pela interpretaç o freq encial e, sobretudo, resolver os principais paradoxos da teoria qu ntica. A nova interpretaç o é subscrita pelo indeterminismo metaf sico, a doutrina segundo a qual o cosmo está arraigadamente impregnado por um elemento de acaso. Mas sustenta-se que o acaso é mais do que mero acaso: os eventos que ocorrem por acaso $n$ os o acidentes extremos, ininteligivelmente destitu dos de causalidade; eles $s$ o resultados parcialmente controlados pelas situaç es $\mathrm{f}$ sicas, de onde prov $\mathrm{m}$. Infelizmente, a seç o central 'Uma defesa das propens es' (1983(b), Parte II, §20) que introduz a interpretaç o propensional, notadamente n o faz justiça sua originalidade; também em outras partes do Postscript, Popper 
tende a representá-la simplesmente como um ajuste ou correç o da interpretaç o freq encial (que, na aus ncia de qualquer outra, $\mathrm{f}$ sicos como von Neumann 1936, cap tulo Iv.1, freq entemente acatam). Mas, certa ou errada, a interpretaç o propensional representa um acréscimo radical para nossa compreens o da probabilidade $\mathrm{f}$ sica, que legitima as probabilidades de um único caso. De acordo com a interpretaç o freq encial, pode-se atribuir probabilidade a um único resultado somente se ele for tomado como elemento de um coletivo; por exemplo, a probabilidade de que uma part cula individual seja transmitida até um obstáculo faz sentido somente se a part cula for referida a alguma classe de part culas. Como a freq ncia de transmiss o pode ser diferente em classes diferentes, nem há um coletivo único e tampouco existe uma probabilidade de um único caso n o amb gua. Poder amos sugerir que a verdadeira probabilidade de um resultado é sua freq ncia no coletivo mais estreitamente definido que o contém, mas isso reduz todas as probabilidades de um único caso a 0 ou 1 , um resultado conveniente somente para os deterministas. Há, na verdade, uma perspectiva subjetivista, que compreende a probabilidade do resultado de um único ensaio como sendo sua freq ncia no coletivo mais estreitamente definido qual se sabia, antes do evento, que ele pertencia. Nesta concepç o, é apropriado falar de probabilidade somente porque n o sabemos o suficiente. Esta posiç o deve, por sua vez, ser cuidadosamente distinguida da posiç o subjetivista com respeito ao acaso, a que Popper, ansioso por evitar a especulaç o metaf sica, recorreu, relutante, em 1934(b), §69. Ela era uma das teses do $\$ 62$ desse livro, elaborada nos $\$ \S 3-6$ de 1982(b), segundo a qual empregamos a probabilidade $n$ o para atenuar a ignor ncia, mas porque é o que a situaç o-problema exige: quest es estat sticas - tais como aquelas relacionadas intensidade de linhas espectrais - demandam respostas probabil sticas ou estat sticas. A incapacidade para dar sentido adequado $\mathrm{s}$ probabilidades de um único caso é uma conseq ncia inevitável da associaç o de um tratamento objetivista da probabilidade com uma interpretaç o subjetivista do acaso. O Postscript renunciou última e procurou fornecer uma teoria das probabilidades objetivas de um único caso.

Reconhecendo que o indeterminismo implica que o estado presente do mundo pode, em princ pio, evoluir em diferentes estados futuros poss veis, devemos permitir que essas possibilidades distintas n o sejam necessariamente iguais; e se f ssemos perseverantes e estivéssemos dispostos a procurar para além das apar ncias, poder amos desejar também atribuir 
essas desigualdades a algum aspecto do estado presente do mundo. Popper sugere que o estado presente possui propens es, forças ativas cuja resultante indeterminada; e é a intensidade da propens o de um resultado particular que temos em mente quando atribu mos a ele uma probabilidade de um único caso. Quando cada part cula em um feixe alcança um obstáculo, por exemplo, há uma propens o de transmiss o (bem como propens es de reflex o e absorç o); conseq entemente, há uma única probabilidade de transmiss o que é independente de outras part culas (embora, se houvesse part culas similares, a probabilidade poderia ser a mesma). $\mathrm{N}$ o podemos medir diretamente a propens o de um único evento, uma vez que ele ocorre ou n o; probabilidades de um único caso podem, portanto, ser propriamente chamadas de metaf sicas. Propens es constantes podem, de fato, ser medidas, de modo mais ou menos preciso, pelas freq ncias, mas isto $\mathrm{n} o$ significa um retorno interpretaç o freq encial ou a uma variante dela. $\mathrm{O}$ que a interpretaç o propensional faz, em suma, é trazer vida o termo n o interpretado ' $P$ ' (probabilidade) do formalismo usual da teoria da medida. A publicaç o de partes do Postscript, muitos anos antes do aparecimento do próprio livro, levou a uma ampla aceitaç o da inovaç o de Popper, de uma forma ou de outra. Todavia há dois enganos particularmente comuns que necessitam de correç o, ambos provenientes de uma assimilaç o ing nua das propens es por aquelas propriedades disposicionais (tais como massa ou condutividade) que s o normalmente atribu das a corpos materiais. Em primeiro lugar, as propens es n o residem em coisas individuais; elas $\mathrm{s} o$ 'propriedades $\mathrm{f}$ sicas objetivas da situaç o f sica considerada e, em última inst ncia, de todo o mundo f sico' (1982(b), Introduç o, §4). Em segundo lugar, as propens es fundamentais $\mathrm{n}$ o $\mathrm{s}$ o propens es para produzir freq ncias. A interpretaç o propensional, diferentemente da interpretaç o freq encial, n o está restrita a efeitos ou experimentos reprodut veis (1982(b), Introduç o, §3, nota 63). Mesmo o que conta como uma repetiç o de um experimento é diferente: os teóricos da propens o tratam duas situaç es como similares porque, eles conjecturam, elas possuem a mesma distribuiç o de probabilidade (propensional); para os teóricos da interpretaç o freq encial, é o inverso.

A interpretaç o propensional seria invalidada se o universo se mostrasse determin stico; invalidada, quer dizer, como uma interpretaç o de probabilidades diferentes de 0 e 1 . Uma das principais tarefas do Postscript era demonstrar que o debate entre determinismo e indeterminismo, embora 
inevitavelmente metaf sico, admite uma discuss o racional. Logik der Forschung tentou fortemente evitar uma especulaç o metaf sica (ver 1959(a), $\$ 69$, nota $* 2$ ) e recusou endossar o indeterminismo em voga da interpretaç o de Copenhague da mec nica qu ntica. A impreditividade de alguns fen menos foi admitida - de fato, como notado abaixo, esta foi a base da interpretaç o de Popper sobre as fórmulas de incerteza como relaç es de espalhamento -, mas se argumentou que isso $\mathrm{n}$ o pesava a favor do indeterminismo nem contra ele (\$78). Em outras palavras, Popper deixou aberta a possibilidade de uma interpretaç o determinista dos fen menos casuais em termos de variáveis ocultas. Mas como a quest o n o podia ser empiricamente decidida, ele $\mathrm{n}$ o a considerou; $\mathrm{n}$ o que ela careça de significado, mas é melhor n o discuti-la. Ao escrever o Postscript, essa precauç o com a metaf sica havia sido mitigada e as tend ncias empiristas do falseacionismo generalizavam-se para um racionalismo cr tico (1945(c), cap tulo 24) que se disp e a considerar qualquer hipótese que possa ser criticada (seja pela evid ncia emp rica ou n o). Dada a afinidade entre determinismo e historicismo, n o é surpreendente que Popper tenha optado pelo indeterminismo. Em 1945(c), cap tulo 13, e em argumentaç es com Einstein em Princeton em 1950, ele descreveu o indeterminismo (o 'livrearb trio', se desejar) como a posiç o do senso comum e n o 'uma condiç o necessária de uma ci ncia que pode fazer prediç es'. Em The open universe 1982(a), sustentou que os únicos argumentos contrários s o aqueles (o dem nio de Laplace) que extrapolam o xito preditivo da ci ncia, especialmente da f sica clássica; e que, portanto, para exibir o determinismo como um dogma n o fundamentado, em conflito com o senso comum, é suficiente mostrar que há limites para o que a ci ncia pode predizer. Ele apresentou tr $\mathrm{s}$ argumentos principais; nenhum deles alude interpretaç $\mathrm{o}$ das fórmulas da incerteza como relaç es de espalhamento. Um deles, hoje bem conhecido, apela para a exist ncia de sistemas din micos instáveis (\$14); baseando-se amplamente em uma discuss o presciente de Duhem (1906, Parte II, cap tulo III, §3), Popper citou um resultado de Hadamard (1898) que mostra que, sobre certas superf cies de curvatura negativa, trajetórias qualitativamente distintas podem afastar-se dos pontos de partida que est o arbitrariamente próximos. $\mathrm{O}$ segundo argumento, mais original e ainda mal compreendido, ataca a possibilidade de prediç o a partir de dentro, quer dizer, a possibilidade de que um expediente preditivo antecipe corretamente sua própria atividade futura (§22; e também 1950(b)(c)); há, 
aqui, conex es com os fen menos de prediç es que se satisfazem (e se frustram) a si mesmas, discutidos de forma resumida em $1957(\mathrm{~g}), \S \S 5 \mathrm{~s}$. Um terceiro argumento apela para a relatividade especial; para a possibilidade de que eventos fora do cone de luz e, portanto, incognosc veis, no momento em que uma prediç o é feita, podem estar dentro do cone de luz e ser causalmente eficazes, no momento para o qual a prediç o é feita (\$19). Nenhum desses argumentos é suficiente para eliminar o determinismo, uma vez que a proximidade do futuro é, como Popper bem sabia, compat vel com a nossa incapacidade de prediz -lo. Ele, portanto, ofereceu vários argumentos mais intuitivos, como também um argumento, que se deve a Landé (1955), destinado especialmente a eliminar a possibilidade de variáveis ocultas determin sticas (\$29). Este argumento assume uma das teses favoritas de Popper de que uma conclus o estat stica sempre requer premissas estat sticas; uma tese que se torna duvidosa, ou mesmo contraditória, pelas evoluç es pseudo-aleatórias de alguns processos din micos n o-lineares.

A alternativa subjetivista, segundo a qual uma conclus o estat stica sempre deriva de uma suposiç o de ignor ncia, era o principal alvo de Quantum theory and the schism in physics 1982(b), o terceiro volume do Postscript. Popper, com veem ncia, contestou a infiltraç o desse subjetivismo na mec nica estat stica, onde produziu pronunciamentos tais como o de Pauli: 'a entropia de um sistema ... depende de nosso conbecimento do sistema.... Se este nosso conhecimento é maximal ... ent o a entropia é sempre zero' (1954, p. 114s., citada no $\$ 5$ de 1982(b)). Contra esta vis o de que, em um estado ideal de conhecimento, a estat stica depereceria, ele escreveu que 'é claramente absurdo acreditar que moedas caem e moléculas colidem aleatoriamente porque n o conbecemos as condiç es iniciais' (\$3). O ataque ao subjetivismo teve seq ncia na teoria qu ntica, cujos principais enigmas, Popper argumentou, surgem por causa de dois erros: a rejeiç o positivista daquilo que está oculto e a tentativa de acrescentar interpretaç o estat stica de Born um determinismo subjacente. Apoiado na interpretaç o propensional da probabilidade, ele prop s estender a discuss o realista de 1934(b), em que se defendeu que as relaç es de incerteza, por exemplo,

$$
\Delta x . \Delta p_{x} \geq b / 4 \pi
$$

estabelecem limites absolutos n o para os estados precisos de part culas individuais, mas para a homogeneidade estat stica de classes que podemos 
preparar. As relaç es de incerteza nada dizem sobre o que podemos medir, muito menos acerca do que é verdadeiramente o caso, mas apenas acerca do que pode ser predito. Reconheceu-se ent o que Popper estava no caminho correto, pelo menos; a impreditividade da posiç o e momento de uma part cula, além de um n vel de precis o, n o elimina a possibilidade de que valores mais precisos dessas quantidades possam ser calculados a partir dos resultados de medidas posteriores. As relaç es de incerteza n o implicam que posiç es e momentos precisos jamais possam ser conhecidos - muito menos que n o haja sentido falar sobre a trajetória de uma part cula, como o positivismo da interpretaç o de Copenhague pretende -, apenas que existem detalhes que $\mathrm{n}$ o podemos conhecer de antem o. A interpretaç o propensional faz muito sentido aqui; de fato, as relaç es de incerteza podem ser compreendidas como enunciando condiç es sobre a propens o de que uma part cula assumirá um certo momento (posiç o), dado que ela é forçada a uma certa posiç o (momento). Mas a nova perspectiva também nos habilita, como Popper sugeriu ( $\$ 18)$, a tratar de dificuldades tais como o experimento das duas fendas. O segredo é simplesmente que as propens es s o um aspecto da 'situaç o f sica considerada e, em última inst ncia, de todo o mundo f sico' (já citado). Um anteparo com uma fenda aberta evoca uma distribuiç o propensional diferente da que é evocada por um anteparo com duas fendas abertas. Que a distribuiç o possa mudar instantaneamente ou 'com velocidade superior da luz', quando uma fenda está aberta ou fechada, n o é um efeito qu ntico misterioso, mas um fato trivial da teoria da probabilidade. (A teoria qu ntica deve explicar por que ela muda do modo como o faz.) Um fliperama fornece um exemplo clássico e simples exatamente com o mesmo tipo de efeito (teses 8 e 9 de 1967(k), inclu das na Introduç o 1982(b)). Em geral, isso é tudo que há para a 'reduç o do pacote de onda' (1934(b), seç o 76; 1982(b), §§8, 23). Evidentemente, o caráter instant neo da mudança é problemático para aqueles que interpretam a probabilidade em termos subjetivistas; pois, nessa interpretaç o, a probabilidade deve mudar apenas com a mudança de informaç o subjetiva, que, portanto, teria de ser transmitida com uma velocidade superior da luz.

Em 1934(b), §77, Popper esperava selar sua cr tica interpretaç o de Heisenberg das relaç es de incerteza, com um experimento imaginário que demonstrasse sua inconsist ncia com o formalismo da mec nica qu ntica. Embora este experimento estivesse viciado por um 
erro, ele pode ter influenciado o pensamento que conduziu ao experimento imaginário de Einstein / Podolsky / Rosen em 1935 (Jammer 1974, p. 174-178; 1982(b), Prefácio, §v, nota 20). O próprio experimento de EPR indica que a aç o instant nea a dist ncia é uma conseq ncia de qualquer interpretaç o do formalismo que negue que as part culas possuam, simultaneamente, posiç es e momentos precisos. Mas, posteriormente, experimentos, como aqueles sugeridos por Bohm e aqueles realizados de fato por Aspect, indicam que podem existir violaç es genu nas ao princ pio da localidade. A resposta de Popper a esses desenvolvimentos posteriores foi conceder que a aç o a dist ncia talvez deva ser aceita na $\mathrm{f}$ sica moderna (assim como foi aceita na f sica clássica). $\mathrm{O}$ experimento de Aspect, ele declarou, seria ent o 'o primeiro experimento crucial entre as interpretaç es de Lorentz e de Einstein acerca das transformaç es de Lorentz' (nota do Autor 1982(b)). Todavia ele posteriormente chegou a duvidar de que o princ pio de localidade foi alguma vez violado e defendeu uma vis o que está menos em harmonia com a ortodoxia corrente.

Por muitos anos, Popper esteve quase sozinho na luta contra o que ele considerava ser uma ortodoxia asfixiante que dominava a teoria qu ntica, embora permanecesse vontade ao lado de Einstein e de de Broglie, que estavam dentre os que dela duvidavam. Estava muito encantado com a publicaç o de Ballentine (1970) em Reviews of modern physics. Ele se op s tanto intrus o do 'observador' na ci ncia objetiva como suposta revelaç o de que a mec nica qu ntica conduzira pelo menos uma área da f sica completa realizaç o. Ele n o estava apenas convencido de que esta última idéia se baseava em uma má interpretaç o do formalismo qu ntico; criticou-a como intencionalmente obscurantista e, se tomada seriamente, pelo perigo de tornar-se uma profecia que se satisfaz a si mesma. A mensagem animadora com a qual 1934(b) era finalizada dizia que a ci ncia é uma investigaç o infindável e que a oportunidade de fazer novas descobertas revolucionárias n o deve ser comprometida. Essa 'busca da verdade, persistente e abertamente cr tica' ( 85 ), ele nunca a abandonou.

Embora o Postscript seja, em grande parte, como se notou, um tratado de filosofia da ci ncia f sica, articulado pela interpretaç o propensional da probabilidade, o primeiro volume, Realism and the aim of science 1983(b), contém aproximadamente 300 páginas de novas discuss es acerca dos problemas da induç o e da demarcaç o, uma defesa do realismo, uma cr tica do instrumentalismo e um outro ataque idéia de que o grau 
de corroboraç o pode ser identificado com probabilidade. Cabe mencionar aqui apenas dois pontos de especial interesse: um importante argumento contra a possibilidade da lógica indutiva, que salienta o fato de que as novas teorias $\mathrm{f}$ sicas caracteristicamente contradizem a evid ncia sobre a qual se sup e que estejam baseadas; e uma cr tica espirituosa da doutrina positivista de que a divis o entre ci ncia e n o-ci ncia é uma divis o entre o que pode e o que $\mathrm{n}$ o pode ser dito. $\mathrm{O}$ primeiro ponto pode ser brevemente resumido: por exemplo, de acordo com a teoria de Newton, as órbitas el pticas postuladas pelas leis de Kepler s o perturbadas por forças interplanetárias. Todavia, as leis de Kepler $\mathrm{n}$ o fornecem indicaç o alguma de quais ajustes s o necessários para se chegar a uma teoria mais geral. Como Whewell (1860, p. 509) disse: 'A prova de Newton de que esta [a órbita el ptica] era o resultado de uma força central ... era a soluç o de um problema no qual seus contempor neos tinham trabalhado em v o.' Duhem também notou que o processo envolvido n o possui um sentido lógico (1906, Parte II, cap tulo vi, §4); é a invenç o de uma hipótese mais profunda. Popper ent o sugeriu que podemos considerar a correç o de uma teoria predecessora (ou da evid ncia) por um nova teoria como uma condiç o suficiente para um aumento de profundidade $(\$ 15)$. Em contraste com a superficialidade covarde do positivismo e do instrumentalismo, o realismo encoraja-nos a penetrar cada vez mais profundamente na constituiç o do universo.

Se a marca caracter stica do $\mathrm{C}$ rculo de Viena estava baseada no lema de Waismann, de que 'o significado de um enunciado é o método de sua verificaç o' (e, portanto, a metaf sica carece de significado), sua orquestraç o mais ambiciosa deveu-se a Carnap que, seguindo Wittgenstein, prop s a tese de que, em uma linguagem ideal ('a linguagem da ci ncia'), apenas enunciados cient ficos verificáveis poderiam ser formulados e os pretensos enunciados metaf sicos seriam vistos como pseudo-enunciados, ru dos n o-gramaticais. Em sua primeira forma original, esta idéia foi destru da pelo reconhecimento (pelo qual Popper merece bastante crédito, muito embora remonte a Hume) de que as hipóteses cient ficas, sendo espaço-temporalmente universais, nunca s o verificáveis. Mas a car ncia de significatividade da metaf sica logo foi identificada por Carnap com sua n o-testabilidade e o dogma da linguagem da ci ncia adquiriu uma nova roupagem. A posiç o de Popper nessa história é meticulosamente apresentada em um artigo escrito por volta desta época (1963(a), cap tulo 11). A discuss o em 1983(b) do que Popper chamou 'a filosofia cambiante 
do sentido e do sem sentido' contém, pelo menos, uma preciosidade ( $\$ 24)$. Para estabelecer que pertencer ci ncia tem pouco a ver com pertencer a uma linguagem cient fica e que a testabilidade tem pouco a ver com a forma lógica, Popper mostrou que duas das mais famosas conjecturas n oresolvidas acerca da teoria elementar dos números podem ser expressas quase com o mesmo vocabulário e formuladas exatamente com a mesma forma lógica, todavia uma é falseável por inspeç o de um número finito de inteiros positivos e a outra (de acordo com o conhecimento atual) n o é falseável. Podemos formular as duas conjecturas do seguinte modo (o dom nio das variáveis é o conjunto de inteiros positivos):

$$
\begin{aligned}
& \forall x \exists z[\operatorname{primo}(x+z) \wedge \operatorname{primo}((x+2)-z)], \\
& \forall x \exists z[\operatorname{primo}(x+z) \wedge \operatorname{primo}((x+2)+z)] .
\end{aligned}
$$

Popper notou que se a conjectura (1) de Goldbach é uma express o gramaticalmente correta, em uma linguagem significativa, também o é a conjectura de primos g meos (2). Mas enquanto a primeira, se falsa, é finitamente falseável, a última $\mathrm{n}$ o o é. A testabilidade $\mathrm{n}$ o deve ser identificada com significatividade. De fato, por muito tempo Popper entendeu que embora alguma metaf sica tenha mérito duvidoso, em geral ela n o carece de significado e pode mesmo ser um componente essencial da ci ncia. O atomismo foi um exemplo t pico de uma teoria metaf sica que pouco a pouco tornou-se testável e cient fica (1934(b), §4). O próprio Postscript notou que os programas metaf sicos de pesquisa s o ub quos e sugeriu que a maior parte das atividades cient ficas, desde a seleç o dos problemas até o endosso das soluç es, tem lugar sob a orientaç o de um ou outro programa. Em seu cap tulo conclusivo, 'Um ep logo metaf sico', Popper listou dez programas, desde o mundo estático de Parm nides até o mundo estat stico de Born, que influenciaram o desenvolvimento da teoria da matéria, e ofereceu uma breve história, particularmente útil, da mudança na situaç o-problema metaf sica, desde Descartes até Faraday (1982(b), §20). Uma vis o do mundo em termos de campos de propens es foi proposta como um novo programa de pesquisa que solucionaria muitos dos problemas existentes na interpretaç o de teorias $\mathrm{f}$ sicas. A idéia é desenvolvida, posteriormente, em 1990(f).

É dif cil avaliar qual o impacto que o Postscript poderia ter tido se tivesse sido publicado 25 anos antes. Algumas de suas teses centrais - de 
que existem limites para a preditividade, mesmo na f sica clássica, de que a interpretaç o de Copenhague n o é a última palavra em microf sica, de que as teorias cient ficas $\mathrm{t} \mathrm{m}$ de ser falseáveis, de que a ci ncia caminha com a metaf sica - est o atualmente entre os lugares-comuns. Dificilmente isto seria verdadeiro em meados dos anos 50, quando o livro foi escrito. Mas existe óbvia exceç o: a tese de que a induç o é mero sofisma ainda $\mathrm{n}$ o se tornou um lugar-comum, mesmo entre aqueles cujo trabalho, na vis o de Popper, melhor ilustra que sofisma ela encerra.

\section{Na LSE, 1960-69}

Por muitos anos, Fallowfield foi o retiro para o trabalho intelectual. Em seu escritório, observando a relva, Popper sempre escrevia m o, produzindo complexos amontoados de páginas com várias correç es, cortes e inserç es. Hennie dedicava a todos os textos sua incisiva atenç o cr tica, depois os datilografava produzindo quatro ou cinco cópias de carbono, prontas para a próxima rodada de revis es. Quando tinha tempo, ela trabalhava no jardim, mas ocupava grande parte de seu dia no chamado quarto de livros, tentando organizar o fluxo incessante de papel que lhe chegava do mundo exterior. Poucos itens eram descartados, mas n o havia nem mesmo um arquivo para organizar os amontoados de pastas e envelopes precariamente empilhados nas estantes. Posteriormente, Popper também teve um secretário na LSE, que cumpriu um papel crucial na produç o dos textos finais. Pelas $m$ os do assistente de pesquisa passava toda vers o de cada parte dos escritos filosóficos; comentários e sugest es, visando a aperfeiçoamentos, eram encorajados e introduzidos em todos os $\mathrm{n}$ veis e estágios. Com efeito, o assistente tornou-se um aprendiz, afora Hennie, a mais influente e ativa parceira nos negócios (Agassi 1993, cap tulo 4). No tempo livre que dispunha, Popper se deleitava lendo as novelas de Austen e Trollope - das quais ele tinha uma memória quase que fotográfica -, mas, na verdade, havia pouco tempo dispon vel para o lazer em Penn. Em dias normais, mesmo as refeiç es eram distraç es. Hennie $\mathrm{n}$ o gostava muito de cozinhar e era comum as visitas receberem apenas lanches ou biscoitos, café solúvel ou chá. Popper jamais tomou bebida alcoólica - algumas vezes mencionava a degradaç o que ele presenciou em Viena durante sua juventude - e raramente ele a oferecia. 
Mas as visitas (n o os colegas ou assistentes), em certas ocasi es, poderiam se servir de um bom xerez, nas quais Hennie os acompanhava. Ela era muito mais sociável dentro de sua casa do que fora e como a avers o de Popper a cigarro aumentava, sem mencionar suas dificuldades em ouvir o que era dito quando havia alguma conversa de fundo, eles permaneciam cada vez mais em Penn, sempre recebendo gentilmente visitas, mas retribuindo muito pouco. Todavia, pelo volume de trabalho que se fazia, havia pouca press o. Bondi falou da 'atmosfera puramente intelectual, na qual pensamentos e aç es $\mathrm{n}$ o-intelectuais n o tinham lugar exemplificada ali com clareza, beleza e generosidade' (Bondi 1995, p. 7). No ver o, muitas tardes agradáveis seriam passadas na mesa do terraço ou andando pelo campo, uma ampla área gramada que se estendia do jardim, ouvindo - e intermitentemente intervindo - enquanto Popper investigava novas idéias.

Popper foi eleito membro da Academia Brit nica em 1958. Na Confer ncia Filosófica Anual da Academia, em janeiro de 1960 (1963(a), Introduç o), ele explicitamente comparou a quest o epistemológica 'Como voc conhece?' com a quest o pol tica 'Quem deveria governar?', sustentando que cada uma foi responsável por imensos equ vocos autoritários. A quest o pol tica, que foi examinada no cap tulo 7 de The open society, é potencialmente paradoxal e deve ser substitu da pela quest o mais sensata 'Como podemos organizar as instituiç es pol ticas de modo que os governantes maus e incompetentes possam ser impedidos de causar muitos preju zos?'. Analogamente, a resposta sensata quest o 'Como voc conhece?' é 'Eu n o conheço. Como posso melhorar minha opini o?'. O modo como hipóteses e evid ncias na ci ncia aju zam hesitante e flexivelmente umas as outras, ele sugeriu, é similar ao modo como o governo e o eleitorado, em uma democracia liberal, exercem um controle limitado porém aut ntico sobre cada uma das aç es do outro. As chamadas teorias do controle mútuo, embora muito perigosas, operam surpreendentemente bem na prática, desde que tenham lugar nas instituiç es adequadas. Parece razoável concluir que a ci ncia também deve ser capaz de se desenvolver sem apelar para autoridades últimas. Anarquia $[=$ ceticismo $]$ e tirania $[=$ dogmatismo $]$ n o esgotam as alternativas.

Um outro passo importante, de natureza bem diferente, foi a tentativa de Popper, em 1960, de fornecer uma definiç o técnica da idéia 
de verossimilitude ou aproximaç o da verdade, que se distingue nitidamente da idéia de probabilidade, que é uma medida da aproximaç o da certeza (ver 1963(a), cap tulo 10, §§XI-XIv). Essa tentativa teve - se a express o pode ser usada - um fracasso espl ndido. Pois embora a própria definiç o de Popper se mostrasse, em 1974, insatisfatória, sua refutaç o inspirou muitos trabalhos de outras pessoas, fornecendo uma ilustraç o oportuna da tese de que nosso conhecimento cresce pela invenç o de novas hipóteses e pelo seu exame cr tico. O problema original aqui era explicar como o progresso é poss vel na ci ncia, se tantas teorias cient ficas, mesmo as que empiricamente obtiveram maior xito - tais como as leis de Kepler ou a teoria de Newton -, s o refutadas com o tempo. (O expediente instrumentalista, que alega que uma teoria refutada permanece 'verdadeira dentro de seu campo de aplicaç o', n o é admitido pelos falseacionistas.) Definindo o conte do de verdade $B_{V}$ e o conte do de falsidade $B_{F}$ de uma teoria $B$ como sendo, respectivamente, os conjuntos de suas conseq ncias verdadeiras e de suas conseq ncias falsas, Popper prop s uma elucidaç o sedutoramente simples da idéia de que $C$ mais veross mil do que uma rival $A$ (ou est mais pr xima de toda a verdade do que $A$ ). Em suma, $A_{V} \subseteq C_{V}$ e $C_{F} \subseteq A_{F}$; ou seja, $C$ deve aumentar os xitos de $A$ (ou, no pior dos casos, n o perder nenhum deles) e deixar de cometer alguns de seus erros (ou, no pior dos casos, n o acrescentar outros). Todavia, pode-se mostrar que a relaç o entre teorias falsas jamais é t o simples quanto essa, infelizmente; de fato, a definiç o n o permite que uma teoria falsa esteja objetivamente mais próxima da verdade do que uma teoria rival (verdadeira ou falsa). Popper respondeu de diferentes maneiras ao impacto sobre sua filosofia deste resultado e de resultados negativos afins: 1976(h) e 1979(a), Ap ndice 2, s o enigmáticos mas dignos de apreço; 1983(b), Introduç o, §v, é mais desafiante. Talvez seja razoável dizer que, encantado por uma definiç o que descobriu ser, 'de fato, muito bela' [294.6], ele n o se preocupou em exp -la a uma cr tica severa; se assim procedesse, rapidamente descobriria que era insatisfatória. Uma volumosa discuss o subseq ente $\mathrm{n}$ o conseguiu resolver a quest o e a situaç o atual parece ser a de que, embora os realistas (que decerto acreditam na verdade) estejam, em geral, confiantes em que faz sentido dizer que uma teoria (por exemplo, a relatividade geral) está objetivamente mais próxima da verdade do que outra (como a mec nica clássica), sendo assim, portanto, um exemplo de progresso cient fico, ninguém pode apresentar uma caracterizaç o logicamente segura que explique em que consiste tal progresso. 
Um terceiro avanço, no in cio da década de 60, foi em filosofia da biologia. As concepç es biológicas est o por trás de muitas das primeiras propostas metodológicas de Popper, pois aprender por tentativa e erro é, como ele percebeu, um processo darwiniano de seleç o pelo meio ambiente, enquanto a induç o - se existisse - se assemelharia a um processo lamarckiano de instruç o. (Assim como a seleç o natural é freq entemente confundida com a herança de caracteres adquiridos, o aprendizado por tentativa e erro é muitas vezes confundido com a induç o.) Talvez seja surpreendente que a teoria de Darwin, e em geral a biologia, tenha sido até esse ponto t o pouco mencionada nos textos de Popper. A apresentaç o mais contundente foi a afirmaç o, em 1957(g), §27, de que a teoria evolucionária é uma hipótese histórica e que n o pode haver lei de evoluç o; existe também uma refer ncia interessante em 1979( $\left.z_{2}\right)$, §4, escrito no in cio dos anos 30 para Jennings (1906). Havia um retrato de Darwin no escritório de seu pai (o outro retrato era de Schopenhauer) e ele guardava com carinho esta lembrança; e entre os cientistas, os biólogos (Eccles, Medawar, W chtersh user), de maneira notável, foram partidários das idéias de Popper. Sem dúvida, foi sua preocupaç o com a análise lógica do processo de descoberta cient fica, e n o com sua descriç o, que o manteve t o distante da articulaç o do que posteriormente passou a ser conhecida como epistemologia evolucionária. A similaridade entre o falseacionismo e o darwinismo foi tematizada na Confer ncia Herbert Spencer de 1961 em Oxford (1972(a), cap tulo 7), onde Popper falou livremente da 'seleç o natural de hipóteses', insistindo em que o significado da express o era literal. Evidentemente, há diferenças entre o crescimento da ci ncia e a evoluç o da vida; em particular, ele observou o n tido contraste entre a diferenciaç o crescente, $\mathrm{t}$ pica da evoluç o biológica, e a integraç o e a unificaç o crescentes, t picas do conhecimento cient fico puro. Neste estágio, ele n o tinha desenvolvido a aplicaç o mais sutil das categorias evolucionárias ao conhecimento cient fico, o que ficou evidente, por exemplo, em sua segunda Confer ncia Spencer de 1973 (1994(r), cap tulo 1); a ci ncia n o era mais comparada a uma populaç o de hipóteses lutando pela sobreviv ncia, mas a um órg o humano, exosmoticamente desenvolvido e sujeito a uma seleç o n o-natural (cr tica). $\mathrm{O}$ ponto crucial, contudo, é o processo, n o o meio. Voltando-se para a psicologia da escola de W rzburg, Popper começou a ressaltar cada vez mais a similaridade das fases (de soluç o de problemas) do aprendizado e do 
desenvolvimento biológico, finalmente (1972(a), cap tulo 6, §xviII) condensada no esquema

$$
\begin{aligned}
& P_{1} \rightarrow T S \rightarrow E E \rightarrow P_{2} \\
& \quad(\text { problema - tentativa de soluç o - eliminaç o de erro - novo(s) problema(s)). }
\end{aligned}
$$

Na confer ncia de 1961, Popper também procurou dar uma contribuiç o própria biologia evolucionária, oferecendo uma hipotética explicaç o darwiniana da ortog nese; em primeiro lugar, enfatizando (como fizeram Baldwin e Hardy) que as prefer ncias de um organismo podem, ao remodelar seu nicho ecológico, ter um impacto direto sobre o desenvolvimento evolutivo (é claro, sem ter impacto algum sobre os genes) - isto ele chamou de 'darwinismo ativo'- e, em segundo lugar, propondo em particular um modelo ('a teoria spearbead (ponta-de-lança)') que torna poss vel a um genótipo evoluir de uma maneira que pareça dirigir-se a uma meta. A idéia é que cada genótipo incorpora, de forma mais ou menos independente, prefer ncias e modos de satisfazer essas prefer ncias; que o organismo $\mathrm{n}$ o precisa ser colocado em perigo se a primeira (a estrutura-objetivo) evolui sem uma evoluç o correspondente da última (a estrutura-habilidade); mas que, posteriormente, as mutaç es na base genética da estrutura-habilidade podem capacitá-lo a alcançar. As mutaç es, que muito provavelmente teriam sido letais, poderiam, portanto, tornar-se favoráveis se a base (de objetivos e prefer ncias) já tivesse sido preparada para elas. Um exemplo familiar é o do bico do picapau, cujo estabelecimento bem-sucedido, sugere a teoria spearhead, teria sido mais fácil quanto mais o pássaro tivesse cultivado uma predileç o por bichos que vivem no fundo da casca das árvores. A teoria spearhead foi examinada com algum detalhe e aplicada ao problema corpo / mente, por Watkins (1997).

Parte da motivaç o para um importante congresso internacional em filosofia da ci ncia, que Lakatos, com grande ajuda de outros, organizou em Bedford College (Londres), em julho de 1965, foi ver Popper, recentemente nomeado Sir, frente a frente com dois de seus mais proeminentes opositores nos Estados Unidos. Um deles era Carnap, amigo e adversário desde o tempo de Logik der Forschung, com quem discutiu nos textos sobre lógica indutiva desde o in cio dos anos 50; o outro era T.S. Kuhn, um historiador da ci ncia que assistira aos seminários de Popper, 
em Harvard, em 1950, e que publicara recentemente um best-seller filosófico, The structure of scientific revolutions (1962). Embora o tom de controvérsia pública entre Popper e Carnap, e entre seus defensores, tenha sido freq entemente belicoso, eles se gostavam e se admiravam, e muitas cartas atenciosas foram trocadas por eles durante anos. Popper, posteriormente, escreveu em um necrológio que a influ ncia de Carnap estava baseada em seus grandes poderes construtivos e no fasc nio único de sua personalidade' $\left(1970\left(z_{11}\right)\right)$. O confronto entre eles, em Bedford College, foi estranhamente artificial e eles nunca estiveram $t$ o distantes com respeito induç o. A sess o dedicada ao trabalho de Kuhn n o foi muito mais conciliatória. Kuhn repetiu a célebre contenda (que se deve originalmente a M. Polanyi 1958), na qual o progresso cient fico n o depende, como Popper sempre afirmara, de novas idéias imaginativas sujeitas cr tica severa, mas da suspens o da cr tica e sua substituiç o por uma rotina de soluç o de quebra-cabeças sob os ausp cios do que ele chamou de um paradigma; e sugeriu que os principais desenvolvimentos, especialmente as revoluç es, na história da ci ncia, s o melhor compreendidos em termos sóciopsicológicos do que em termos racionalistas (1970). Os comentários de Popper enfatizaram a estranheza de se transferir sociologia e psicologia, que n o s o as mais desenvolvidas das ci ncias emp ricas, a tarefa de compreender a atividade da ci ncia emp rica. Mais significativo, para Popper, no congresso, foi seu discurso de abertura e uma aflitiva altercaç o com Bartley, um de seus alunos favoritos. Esta n o foi a primeira nem a última vez que Popper e um de seus seguidores foram levados a uma árdua e quase incompreens vel desavença. Nessa ocasi o, suspeita-se que o tom r spido da palestra de Bartley, sentido por Popper como uma forte afronta pessoal, foi encorajado por uma terceira pessoa, que estava determinada a criar caso. Mas nessa ocasi o, diferentemente de outras, o dano foi finalmente reparado. Em 1980, Popper e Bartley voltaram a ser amigos e Bartley incumbiu-se da tarefa extenuante de editar o Postscript. O discurso de abertura, originalmente intitulado 'Racionalidade e a busca de invariantes', retomou a quest o dos programas metaf sicos de pesquisa em $\mathrm{f}$ sica, traçando a história e a predomin ncia do programa (que surgiu com as especulaç es do filósofo pré-socrático Parm nides) de explicar a mudança concentrando-se no que n o muda, de explicar a mudança eliminando-a. Ainda outro trabalho, cuja publicaç o foi por muito tempo adiada, uma confer ncia exaustivamente revista, 
foi recentemente publicado no volume 1999(a) sobre o pensamento présocrático.

A última grande especulaç o filosófica original de Popper, sua 'filosofia dos tr s mundos', que, algumas vezes, foi por ele chamada de 'a filosofia de minha idade avançada', começou a tomar uma forma reconhec vel em 1965, em sua Confer ncia Arthur Holly Compton na Universidade de Washington (St Louis). Intitulada 'Das nuvens e relógios' (1972(a), cap tulo 6), a confer ncia tinha como objetivo contribuir para nosso entendimento da liberdade humana em um mundo que muitos consideram como estando sob o r gido controle das leis da $\mathrm{f}$ sica. Valendo-se novamente do material do Postscript 1982(a) - Popper implacavelmente retomava seus textos -, a confer ncia examinou o pesadelo do determinismo f sico e firmemente o recusou. Todavia, para que existam a liberdade e a criatividade humanas genu nas, Popper ressaltou, $\mathrm{n}$ o é suficiente que nosso comportamento n o seja comple-tamente determinado. Para ser livre - embora n o completamente, é claro devemos ser capazes de controlar até certo ponto - embora n o completamente, é claro - alguns aspectos do mundo $\mathrm{f}$ sico. $\mathrm{O}$ mundo $\mathrm{f}$ sico deve estar causalmente aberto a algumas influ ncias externas, especialmente s influ ncias psicológicas. Essas consideraç es simplesmente reformulam o antigo problema da interaç o entre corpo e mente ('o problema de Descartes'). Mas Popper estava atento a um outro problema, examinado com menos freq ncia, que ele chamou de 'o problema de Compton', o de como as entidades abstratas, tais como reg ras e deci$\mathrm{s}$ es, teorias e melodias, s o capazes de provocar mudanças no mundo $\mathrm{f}$ sico. Os materialistas, aqueles que consideram o mundo como sendo essencialmente material (ou, de maneira mais geral, $f$ sico), formulam esses problemas como problemas de reduç o. A tarefa, vista por eles, é explicar como entidades supostamente mentais e abstratas devem ser constru das como manifestaç es apenas da matéria. Popper nunca apreciou tais concepç es ou outras afins, como o behaviorismo, pela simples raz o de que - embora metaf sica no mais alto grau - elas parecem originar-se de uma avers o positivista metaf sica e n o de um interesse sério pelo mundo. (Apesar disso, evidentemente, elas podem ser interessantes e até verdadeiras.) A Confer ncia Compton prop s que ambos os problemas podem ser tratados pela hipótese evolucionária de que a mente, a linguagem, e a consci ncia s o componentes de uma 
hierarquia de controles que tem evolu do (do modo como se prop s em 1972(a), cap tulo 7) precisamente porque permite ao organismo mais liberdade para propor e avaliar, com compet ncia, as soluç es para os problemas que encontra. Popper lembrou seu público de que 50 anos antes seu professor B hler distinguiu diversas funç es, hierarquicamente organizadas, das linguagens animal e humana ( $\mathrm{s}$ funç es expressiva, de sinalizaç o e descritiva de B hler, Popper acrescentou outras, particularmente a funç o argumentativa). Os controles s o flex veis, nem relógio nem nuvem, como uma bolha de sab o que controla e é controlada pelo ar interno (nota-se, rapidamente, no §(ii), a similaridade com o mecanismo de controle mútuo em um Estado democrático). Popper insistiu em que as unidades de controle superiores, a mente, a linguagem e a consci ncia, embora evolu das a partir de um mundo da f sica pura e inseridas nele, elas mesmas $\mathrm{n}$ o $\mathrm{s}$ o puramente $\mathrm{f}$ sicas, assim como os problemas que os organismos enfrentam n o s o puramente f sicos.

A partir disto, foi um passo relativamente curto para o quadro dos tr $\mathrm{s}$ dom nios distintos, o f sico, o mental e os produtos da atividade mental (humana), o mundo 3 (1972(a), cap tulo 3). O mundo 3, Popper sugeriu, é criado pelas mentes (o mundo 2) e atua sobre o mundo f sico (o mundo 1) somente por meio da intervenç o das mentes. Mas ele é aut nomo, no sentido de que podemos nele descobrir itens que $\mathrm{n}$ o foram conscientemente colocados lá; por exemplo, novos problemas objetivos e conseq ncias n o previstas de teorias previamente inventadas. O princ pio da m nima aç o da mec nica clássica, só para tomar um exemplo simples, foi inventado quando Newton o inventou, mas descoberto apenas quando Maupertius (ou talvez Euler) o descobriu. A teoria dos tr s mundos teve muitos opositores, que a ridicularizaram como ontologicamente extravagante, como uma mula [= obstinada e estéril] e até mesmo n o filosófica. Popper mesmo chamou a atenç o para algumas similaridades superficiais entre o mundo 3 e o mundo das formas de Plat o; mas, como ele notou, as formas de Plat o s o eternas, diferentemente das construç es humanas que habitam o mundo 3. A similaridade entre o mundo 3 e o Esp rito Absoluto de Hegel, também por ele mencionada, parece ser mais próxima, embora a evoluç o do mundo 3 seja mais uma quest o de sorte do que o avanço quase necessário que se sup e caracterizar o Esp rito Absoluto. Assim sendo, a teoria de Popper guarda lugar para uma s ntese necessária - dialética, se se quiser, mas n o hegeliana - do plato- 
nismo e do construtivismo em filosofia da matemática. A autonomia do mundo 3 é revelada mais claramente no modo como a pesquisa continua a levantar novos problemas objetivos em seu interior. A idéia de um problema objetivo pode soar contraditória, mas W chtersh user (1995) chamou a atenç o para a importante posiç o que ela possui na lei alem de patentes. Ilustrando sua tese com o exemplo da teoria das marés de Galileu (1972(a), cap tulo 4, §9), Popper sugeriu que uma melhor compreens o dos importantes eventos na história da ci ncia, em alguns aspectos semelhante ao que se conhece como hermen utica, pode ser alcançada quando se faz um esforço para reconstruir a situaç o-problema objetiva na qual o cientista trabalhou. As teorias cient ficas n o podem ser compreendidas, a menos que compreendamos os problemas objetivos aos quais elas respondem. É importante notar que esta tese, que relativiza a compreens o aos problemas e ao contexto histórico, é plenamente compat vel com a tese antijustificacionista de que a origem de uma teoria n o tem relev ncia para o seu valor de verdade.

Popper fez várias outras visitas aos Estados Unidos nos anos 60 e 70 e participou de muitas confer ncias internacionais. Ele continuou a refinar suas idéias e estend -las a muitas áreas, especialmente filosofia da f sica. Em 1965, ele começou a trabalhar no que planejou ser uma monografia, cujo t tulo seria Exorcizing 'the observer' from modern physics. Ele escreveu dois longos cap tulos sobre as duas teorias da relatividade de Einstein e iniciou um cap tulo sobre mec nica estat stica. A mec nica qu ntica ganhou prioridade quando ele recebeu um pedido para escrever, com urg ncia, um artigo nessa área $(1967(\mathrm{k}))$ e o trabalho sobre o restante da monografia jamais foi retomado (alguns fragmentos foram inclu dos nos $\$ \$ 34-36$ de $1976(\mathrm{~g}))$. Outros artigos de interesse desse per odo s o 1968(q), já mencionado, e 'A responsabilidade moral do cientista' (1994(r), cap tulo 6), que contém, dentre outras propostas, uma 'tentativa de reformular' o juramento de Hipócrates. O fim da década foi uma época dif cil na vida universitária e também Popper n o poderia manter-se inteiramente distante de quest es como a guerra do Vietn e o movimento estudantil. Apesar disso, continuou a trabalhar em Penn. Por alguns anos, teve pouca influ ncia dentro de seu próprio departamento, em parte por sua escolha, em parte porque Lakatos estava concentrando todos os poderes para si. Quando sua aposentadoria e sa da da LSE, em 1969, quase passou despercebida, quietamente terminou-se uma era. 


\section{Aposentado, 1969-94}

Como acontece a muitos daqueles que trabalham exaust o, sempre houve projetos que Popper n o p de finalizar ou mesmo encaminhar. Um deles ent o começou a ser ameaçado: o enorme volume Popper em THE Library of Living Philosophers, uma série que há 30 anos vinha produzindo alguns livros úteis, incluindo o excelente volume Einstein (Schilpp 1949). $\mathrm{O}$ formato dos livros era padr o: uma autobiografia intelectual da $\mathrm{v}$ tima, numerosos ensaios cr ticos e descritivos sobre seu trabalho, suas réplicas $\mathrm{s}$ cr ticas e uma exaustiva bibliografia. Popper completara com xito a autobiografia (mais tarde publicada separadamente como 1976(g)) em 19681970. Trinta e tr s artigos solicitados foram entregues, muitos deles no prazo final, em maio de 1965. Hansen compilara uma detalhada bibliografia (1974). Mas Popper, por anos, foi incapaz de escrever mais de duas ou tr s réplicas e uma breve introduç o a elas. A ameaça de Schilpp, em junho de 1971, de que ele engavetaria por tempo indeterminado o volume Popper, a menos que uma vers o completa até primeiro de setembro estivesse pronta, levou Popper a uma aç o conjunta. Uma pequena equipe de assistentes e datilógrafos foi montada. Ficou combinado que Popper redigiria as principais réplicas e verificaria as vers es finais e que a maioria dos trabalhos intermediários seria realizada fora. Cerca de seis semanas depois, as réplicas estavam redigidas, colocadas no formato, com as refer ncias inclu das, conferidas e reconferidas; ao mesmo tempo, a autobiografia foi editorialmente conclu da. (Em Schilpp 1974, que possui mais de 1300 páginas de texto impresso, as réplicas ocupam cerca de 250 páginas, a autobiografia e a bibliografia em torno de 250 páginas.) Foi imenso o al vio sentido em Fallowfield, no final de agosto, quando Popper passou um telegrama para Schilpp anunciando que '666 páginas foram enviadas hoje'.

A réplica que causou maior dificuldade a Popper - sendo reescrita mais de uma vez - foi dirigida a Lakatos (1974). Este artigo de um excolega, embora expressando admiraç o e benevol ncia, criticou as soluç es de Popper aos problemas da demarcaç o e da induç o com argumentos surpreendentemente sem originalidade ou sofisticaç o. Segundo Lakatos, raramente as teorias cient ficas s o falseáveis, pois caso uma prediç o falhe sempre é poss vel responsabilizar n o a teoria em teste mas algumas das hipóteses auxiliares utilizadas no processo de teste. É bem sabido que um ajuste ad hoc pode salvar uma teoria falseada (remontando, pelo menos, a 
Duhem 1906, Parte II, cap tulo vi, §3, e totalmente reconhecido em 1934(b), §6), mas isso n o mostra que as teorias n o podem ser falseadas; mostra somente que o falseamento freq entemente requer um trabalho árduo, já que 'a natureza $\mathrm{n}$ o fornece uma resposta, a menos que seja pressionada’ (1934(b), §85). A soluç o de Popper ao problema da induç o foi rejeitada por Lakatos pelas raz es especiosas de que, na aus ncia de algum princ pio indutivo metaf sico que conecte o passado ao futuro, a aplicaç o da ci ncia reduz-se ao dom nio da investida irracional. Esta é uma objeç o que somente aqueles que identificam racionalidade com justificaç o podem fazer. (Poucos que de fato identificam racionalidade com justificaç o conseguiram evitar isso.) $O$ ponto de Popper foi sempre o de que devemos conectar o passado ao futuro por meio de uma teoria emp rica e é simplesmente gratuito postular também uma conex o metaf sica. É espantoso que alguém que foi colega por uma década tenha sido incapaz de fazer melhor do que isso; muito menos espantoso é que Popper tenha se irritado ao encontrar o panorama clássico de 1934(b) sendo desfigurado por uma tal extravag ncia filosófica. Houve, depois disso, um rompimento permanente entre Popper e Lakatos, que morreu subitamente antes que Schilpp (1974) aparecesse.

Um dia, em maio de 1971, Peter Krohn casualmente perguntou a Medawar por que Popper n o era um membro da Royal Society e lhe foi dito que a única desculpa satisfatória era que ninguém havia pensado em nomeá-lo. Prontamente, Medawar encarregou-se desta tarefa e começou a conquistar aliados. A eleiç o foi finalmente marcada para junho de 1976 e noticiada com as infelizes palavras '[Popper] foi considerado excepcional porque seu trabalho alterou fundamentalmente os métodos de deduç o usados pelos cientistas' [405.9]. Notando que seus patrocinadores tinham inclu do 'alguns cientistas experimentais rigorosos', Medawar lhe escreveu 'Penso que voc pode considerar que todos que apoiaram seu nome est o mais orgulhosos de serem membros da Royal Society porque voc é agora um de nós' [325.27]. Popper ficou imensamente agradecido com o t tulo, sentindo que sua contribuiç o para a ci ncia foi, enfim, reconhecida. Aparentemente, ele n o percebeu muito bem que $\mathrm{n}$ o foi eleito como um cientista aut ntico, pois, alguns anos depois, telefonou para Medawar, transtornado ao ver seu nome inclu do na lista dos membros eleitos pelo Estatuto 12, junto com pol ticos e outros que n o estavam ativamente envolvidos com a ci ncia. Medawar respondeu com muito tato. Notando 
que Churchill (por quem Popper tinha muita admiraç o, n o só por sua coragem e habilidade pol tica, mas também por seu bom senso filosófico) fora eleito pelo Estatuto 12, ele relatou o ponto de vista do bibliotecário de que 'voc n o poderia ser eleito um candidato de seç o e que a Society estava t o determinada a colocar seu nome em seus livros que eles decidiram que $\mathrm{n}$ o haveria outra opç o a n o ser o Estatuto 12'. 'O problema, na verdade, é insignificante para voc permitir que lhe aborreça', confortouo Medawar [325.29]. Mas Popper n o via exatamente desse modo.

No in cio dos anos 70, como resultado da discuss o em um programa da televis o holandesa, da qual Popper e Eccles participaram em 1971, eles começaram um livro conjunto sobre o problema corpo / mente, 'uma tentativa de cooperaç o interdisciplinar' (p. IX). O resultado, The self and its brain 1977(u), n o é genuinamente uma obra conjunta; contém cinco cap tulos filosóficos e um sumário de Popper, oito cap tulos de Eccles relatando a situaç o atual da pesquisa sobre o cérebro, relacionando-a com o problema da interaç o cérebro / mente, e as transcriç es editadas de vinte diálogos gravados em setembro de 1974, em Villa Serbelloni, no Lago Como, onde os autores eram convidados da Fundaç o Rockefeller. Alguns deles, que ele nomeou como 'os pontos altos dos Diálogos' s o mencionados em Eccles (1982). Sendo dualistas, ou mesmo pluralistas, os autores reconheceram no prefácio algumas sérias diverg ncias de opini o. Em particular, discordavam quanto religi o. Embora as quest es éticas sempre constitu ssem uma parte importante do pano de fundo da filosofia de Popper (KIesewetter 1997; W chtersh user 1995), em sua fase mais madura ele raramente discutia ética e quase nunca quest es religiosas. De fato, uma das caracter sticas de Bartley (1962) que ele mais admirava era o modo como esse livro, que foi uma contribuiç o significativa literatura sobre o racionalismo cr tico, fez com que os dilemas do protestantismo contempor neo parecessem interessantes. Mas ele era simpático posiç o religiosa dos outros e n o estava pronto para endossar vários ataques humanistas e seculares: 'Embora n o seja religioso, penso mesmo que devemos respeitar todos que sinceramente acreditam ...' [297.11]

A contribuiç o de Popper a 1977(u) consiste principalmente em um desenvolvimento das idéias preliminares em 'Das nuvens e relógios', reforçado por uma doutrina mais expl cita de como o sujeito humano, a mente consciente de si mesma, está ancorada no mundo 3; isto é, de como 
a identidade pessoal é sustentada e, em parte, controlada pelos usos descritivo e argumentativo da linguagem. Como Adam Smith reconhecera dois séculos antes, a vida social - da qual o uso da linguagem é uma parte crucial - é uma condiç o essencial para o desenvolvimento pleno da autoconsci ncia. O livro contém uma cr tica detalhada do materialismo e do fisicalismo e uma história breve e encantadora sobre o assunto que, rastreando o dualismo corpo / mente até A Odiss ia, trata de silenciar a doutrina moderna de que a consci ncia do problema da autoconsci ncia começa com Descartes. Mas Popper, privadamente, considerou insatisfatória sua contribuiç o ao livro e, de fato, n o propriamente acabada. Quando se descobriu, em março de 1977, que Hennie, que por algum tempo estivera doente, tinha um tumor maligno, ele parou de redigir e contentou-se em organizar e preparar para a publicaç o o que já havia escrito. Os oito anos seguintes foram terr veis para ambos. Procuraram todo tipo de tratamento, em vários pa ses; alguns proporcionavam uma melhora temporária, outros nenhuma. Durante os melhores per odos, Popper trabalhou t o infatigavelmente como sempre. No final de 1977, em Cambridge, ele deu a primeira Confer ncia Darwin 1978(z), na qual abandonou a concepç o - expressa em 1976(g), §37 - de que a teoria da seleç o natural n o é uma teoria cient fica, mas somente um programa metaf sico de pesquisa para a biologia. A segunda ediç o de 1979(a) contém alguns importantes materiais novos, especialmente sobre a verossimilitude. Seus textos estavam se tornando antológicos e seus livros estavam sendo traduzidos para muitas 1 nguas. Pouqu ssimas vezes Popper contratou os serviços de um agente literário, preferindo assumir todas as negociaç es. Certamente isto era um modo de se manter ocupado, mas, aos poucos, refinou os termos contratuais básicos em que insistia; como um editor estrangeiro disse com relut ncia uns poucos anos antes, 'ele sabe o que quer'. A outra grande demanda, nessa época, era a crescente quantidade de correspond ncia que recebia. Educadores e engenheiros, epidemiologistas e etnógrafos, todos queriam compartilhar seus pensamentos e ser gratificados com sua resposta. Na resposta s cartas - pelo menos quelas que ele abria e n o perdia em seguida -, ele era um modelo de generosidade, embora nem sempre delicado, freq entemente escrevendo muitas páginas $\mathrm{m}$ o em resposta a um simples pedido.

Os segundo e terceiro volumes do Postscript reorganizado foram publicados no ver o de 1982. Em um novo prefácio ao terceiro volume 
1982(b), ele prop s o que esperava ser um experimento genuinamente realizável, que testaria a correç o da interpretaç o de Copenhague da mec nica qu ntica. Esta proposta recebeu alguma atenç o cr tica da literatura cient fica posterior (ColletT \& LOUDON 1987; 1987(t); ver também Redhead 1997, p. 197-203). Aproximadamente na mesma época, antes de completar 80 anos, ele foi indicado para a Order of Companions of Honour. Ele já havia recebido vários outros pr mios e t tulos importantes e as gratificaç es por alguns deles ajudaram-no finalmente a satisfazer sua paix o de comprar e colecionar livros raros. Em 1937, ele conseguira salvar alguns livros da suntuosa biblioteca de seu pai, mas agora fazia compras de modo quase temerário. Esse foi o seu único v cio. $\mathrm{Na}$ época de sua morte, sua biblioteca continha as primeiras ediç es do De magnete de Gilbert, Harmonices mundi de Kepler, Dialogo ... sopra i due massimi sistemi del mondo Tolemaico e Copernicano de Galileu, Leviathan de Hobbes, Treatise de Hume, Discours de Rousseau, das tr s Critiques de Kant, das M moires de chimie de Lavoisier e dos Elements de Lyell; as segundas ediç es dos Principia de Newton e do Sceptical chymist de Boyle, e cerca de 200 outras obras raras sobre temas cient ficos, filosóficos e clássicos, incluindo uma cópia do Aldine Aristófanes de 1498 (Sotheby’s 1995).

Em janeiro de 1982, George Soros, um emigrado húngaro que tinha assistido s confer ncias de Popper na LSE nos anos 50, instituiu, com a calorosa aprovaç o de Popper, o Fundo Sociedade Aberta, oferecendo bolsas de estudo Karl Popper a estudantes negros na África do Sul. Esse foi o primeiro de uma série de agradecimentos de Soros pela profunda import ncia da idéia de uma sociedade aberta, especialmente para aqueles que n o puderam implementá-la, culminando na fundaç o da Universidade da Europa Central, em 1991, em Budapeste, Praga e Varsóvia, e no pr mio Sociedade Aberta, em 1994. 'Seu trabalho serviu de inspiraç o para a Universidade da Europa Central', disse Soros a Popper, em seu discurso de apresentaç o na entrega do primeiro pr mio (Soros et al. 1995, p. 34). The open society foi amplamente estudada em traduç es clandestinas na Europa oriental nos anos 70 e 80 e continua sendo mais apreciada lá (Havel 1995) do que nas democracias liberais mais estabelecidas. 'A pequena revoluç o em meu pa s em 1980-81 teve o seu teórico. Foi voc , senhor!' escreveu, com admiraç o, um estudante polon s em 1982 [284.6]. Acompanhando a desintegraç o rápida e quase pac fica das tiranias socialistas, em 1989 e 1991, que ele insistia em n o ter previsto, Popper 
se interessou muito pela preparaç o da traduç o russa $1992\left(\mathrm{z}_{18}\right)$ de The open society, publicada pela Fundaç o Soros, em Moscou. Em sua mensagem aos leitores russos e reiteradamente nas conversas com amigos, ele falava dos perigos de converter a economia russa em um sistema de mercado antes do estabelecimento de uma tradiç o de prática e cumprimento do direito civil (SIMKIN 1993, p. 198s.; 1996(z 2 ), cap tulo 4).

No final do ver o de 1985, a condiç o de Hennie tinha piorado tanto que os Poppers decidiram retornar, por algum tempo, a Viena, onde ainda moravam vários membros de sua fam lia. Ela passou algumas semanas no hospital, depois de terem alugado uma casa ampla no subúrbio, oeste da cidade, perto de onde foi a antiga regi o de caça do Imperador. Lá, em novembro, ela morreu. Popper, amoroso e rom ntico, mas n o sentimental, rapidamente superou a sua perda e retomou seus múltiplos interesses intelectuais, em particular sobre $\mathrm{f}$ sica qu ntica, teoria da probabilidade e epistemologia evolucionária. Por alguns meses, seus planos para o futuro eram incertos. Havia muito entusiasmo bem-intencionado para manter 'o grande filósofo austr aco’ em seu pa s de origem. Em 1976, ele e Hennie recuperaram a nacionalidade austr aca, embora o motivo para isto tivesse sido a firme expectativa de Popper de que ele morreria antes de sua esposa, que ent o poderia voltar para casa. Mas uma tentativa de convenc -lo, estabelecendo um novo departamento no Instituto Boltzmann $[f r$ Wissenschaftstheorie = para filosofia da ci ncia] na casa em Kramer Gl ckner Strasse, com Popper como Diretor, n o prosperou. No ver o de 1986, ele optou por retornar definitivamente Inglaterra.

Nos oito anos seguintes, ele viveu em Kenley (Surrey), em outra casa, situada em lugar ermo e afastado, semelhante s de Penn e de Viena. (Sem dúvida, isso era o máximo que ele poderia conceder vis o utópica.) Fallowfield fora vendida e a nova casa comprada em seu nome por sua secretária Melitta Mew e o marido Raymond, que estavam se tornando seu principal apoio e fiéis amigos pelo resto de sua vida. Muito mais do que uma secretária, a Sra. Mew (que começou a trabalhar para ele em 1982, em per odo parcial, na LSE) reorganizou, de forma vigorosa porém gentil, quase todos os aspectos da vida e das tarefas do lar de Popper. Arquivos foram instalados e a ordem instaurada em seus negócios (que foram negligenciados por alguns anos). Diariamente, uma empregada (por quem ele sempre foi tratado como 'Professor' - nunca como 'Professor Popper' ou 'Sir Karl') cuidava da casa. Ele vivia confortavelmente, mas sem luxo. Seus aniversários 
eram celebrados com um pequeno almoço para os amigos mais próximos. Ele era muito bem cuidado. Apesar de nem sempre estar fisicamente bem, sofrendo várias vezes pequenas taquicardias e leves derrames, bem como alguns problemas mais sérios, manteve uma independ ncia digna e a mesma vitalidade da mente. 'Estou tendo uma velhice muito feliz', ele disse em muitas ocasi es. Seus amigos compartilhavam de seu bem estar e continuamente se contagiavam com seu entusiasmo e sua generosidade incomum. Muitos visitantes vinham preparados para uma batalha e horas depois estavam desarmados, $\mathrm{n}$ o pelos argumentos mas pelo surpreendente fasc nio. No final de Unended quest, Popper descreveu-se como 'alguém que sente que debatendo idéias encontrava mais felicidade do que poderia merecer'. Em seus últimos anos, talvez pela primeira vez, sua vida foi uma fonte de felicidade genu na.

Em 1986, Popper foi indicado para a primeira Confer ncia Medawar na Royal Society. Ele tinha uma vasta audi ncia, mas a confer ncia sobre 'Uma nova interpretaç o do darwinismo' 1986( $\left.z_{3}\right)$ - infelizmente n o foi das melhores. Isto, talvez, tenha sido motivado pelos transtornos do ano anterior. $\mathrm{Na}$ confer ncia, que $\mathrm{n}$ o foi propriamente redigida e infelizmente nunca foi preparada para publicaç o, ele estabeleceu um programa bastante amplo, que n o p de ser cumprido totalmente. (Algumas das idéias principais da confer ncia s o discutidas informalmente no cap tulo 4 de 1999(h).) Retornando ao tema do darwinismo ativo e identificando a adaptaç o biológica com a aquisiç o de conhecimento, sugeriu que as dificuldades no estabelecimento da vida (tanto natural quanto artificialmente) podem estar mais no fracasso das formas de vida em se adaptarem ao meio ambiente do que na sua criaç o original. Baseando-se na idéia de que a vida se caracteriza pela soluç o de problemas (como esboçado no esquema ( $(\mathbb{\text { I) }}$ acima), algo que ele dizia n o poder ser reduzido qu mica, ele defendia o uso, em biologia, de uma linguagem antropomórfica e mesmo teleológica, sendo a avers o a esta última comparada avers o vitoriana a se falar sobre sexo. O tema constante de que a soluç o de problemas é a chave para uma teoria geral da vida (uma teoria a ser contrastada com a de Schr dinger 1967, segundo a qual se alimentar de entropia negativa é a marca caracter stica; ver $1976(\mathrm{~g}), \S 30)$ foi incorporado no t tulo de um livro de ensaios, 1994(y), publicado logo depois de sua morte. Alguns (por exemplo, Gellner 1996 , p. 80, 84) rejeitaram essas idéias por considerarem um retorno a um romantismo que mal se distingue da Naturphilosophie do século deze- 
nove. Uma cr tica confer ncia Medawar de Popper pode ser encontrada em Perutz (1986).

Um aspecto da vida intelectual de Popper foi que a descoberta de vários novos problemas quase nunca tinha muito efeito sobre seu fasc nio com os antigos; continuamente, ele retomava, com prazer, um tópico de anos passados. Um exemplo notável é o retorno, em 1983(f) e depois em 1987(c), doutrina de que o problema da induç o pode ser solucionado por meio de consideraç es de probabilidade. O renovado ataque a esta doutrina começou com a descoberta, enquanto 1983(b) estava sendo preparado para publicaç o, de um pequeno erro n o notado na Parte II, $\$ 15$; e resultou na afirmaç o de que, mesmo se a probabilidade de uma teoria cient fica $b$ puder ser aumentada pela evid ncia emp rica $e$, esse acréscimo possuirá um efeito exclusivamente dedutivo, dependendo crucialmente da extens o em que os conteúdos de $h$ e de $e$ se superp em. De fato, provou-se que a parte ampliativa $h \leftarrow e$ de uma hipótese $h$ (a parte de $b$ que vai além do que a evid ncia $e \mathrm{diz}$ ) nunca é positivamente sustentada por $e$; em suma, $p(b \leftarrow e \mid e) \leq p(b \leftarrow e)$ para todo $b$ e todo $e$. A conclus o obtida afirmava que, mesmo se existisse uma tal coisa como apoio probabil stico, $\mathrm{n}$ o haveria nada de indutivo nisso: $n$ o existe l gica indutiva. Esse foi um resultado profundamente satisfatório para quem despendeu meio século combatendo aquele que é o mais inexplicável emblema de preconceitos filosóficos.

Mas se houve algum problema intelectual que predominou no pensamento de Popper e que capturou sua imaginaç o, em sua última década, n o foi o problema da induç o nem qualquer outro problema filosófico, mas o problema da origem da vida, brevemente mencionado na Confer ncia Medawar e que, nos diz Popper (1976(g), §5), começou a preocupá-lo com 12 ou 13 anos de idade. Ele esteve profundamente envolvido, desde o in cio, com o desenvolvimento da teoria do mundo de ferro-enxofre de W chtersh user (1988), segundo a qual a vida começou com organismos acelulares e efetivamente bidimensionais, ligados por superf cies carregadas positivamente, como a pirita. W chtersh user, um qu mico que se tornou um advogado especialista em patentes, encontrou Popper em 1982, em Alpbach, um encontro que, segundo ele, 'o fez retornar ci ncia'. Por anos, eles semanalmente passavam horas no telefone discutindo todo aspecto, substancial ou metodológico, da teoria de W chtersh user; foi com muito entusiasmo e orgulho que Popper manteve seus amigos atualizados acerca do progresso da teoria, sua afilhada intelectual, especialmente quando havia 
novos resultados experimentais a relatar $(1990(\mathrm{~g}))$. Sua contribuiç o para o xito da teoria n o deve ser subestimado (W chtersh user 1995, 1997). Foi um exemplo notável de sua curiosidade insaciável e de sua total devoç o busca da verdade.

Quando Popper se tornou mais célebre, mais solicitado e mais venerado, ele novamente se voltou para o mundo exterior. Profundamente angustiado quando jovem, desapontado na meia idade e há anos sem atividade pol tica, ele, em sua velhice, começou a se pronunciar abertamente sobre quest es de interesse público, desde a enormidade do arsenal nuclear soviético até os efeitos nocivos da viol ncia na televis o (1996( $\left.z_{2}\right)$, cap tulos 3 e 7). Em muitas ocasi es, discursou sobre a presunç o e os perigos do nacionalismo $\left(1994\left(\mathrm{z}_{12}\right)\right)$. Cada vez mais falava sobre $\mathrm{o}$ dever moral dos intelectuais em serem otimistas sem serem complacentes, em adotarem o modesto lema do racionalista cr tico 'Eu posso estar errado e voc pode estar certo e, com esforço, podemos nos aproximar da verdade' (1945(c), cap tulo 24, §1) e em abrirem seus olhos s belezas do mundo. Reprovou fortemente a ideologia anticient fica que ele viu no movimento ecológico e parecia confiante em que, embora a ci ncia tivesse admitidamente sido responsável por muitos danos, só ela tinha o poder de corrigir esses erros (1996( $\left.z_{2}\right)$, cap tulo 9). Via com grande preocupaç o a explos o demográfica. Ainda que freq entemente sério e moralista, sempre manteve seu travesso senso de humor. Em 1989, por exemplo, a caminho de Barcelona para receber o pr mio Catalunha, deixou seus companheiros desconcertados ao insistir em que, como uma das condiç es do pr mio era que $\mathrm{n}$ o poderia ser concedido postumamente, ele deveria comprar, com urg ncia, um seguro-viagem equivalente ao valor do pr mio. Ao apresentar uma confer ncia sobre a sugest o de Feynman, segundo a qual um pósitron é um elétron que viaja para trás no tempo, ele duvidou de que seu gerente de banco consideraria seu saque a descoberto como um saldo que se move para trás no tempo. Tinha uma boa vis o para detectar incongru ncias; por exemplo, no modo como tantos artigos publicados nos Proceedings of the National Academy of Sciences dos Estados Unidos s o chamados de 'anúncios'. Quando apresentou uma confer ncia LSE Alumni Association em 1989, solenemente anunciou que, como era sua primeira confer ncia pública na LSE, ele a consideraria uma confer ncia inaugural atrasada; 'é uma ocasi o para a qual estive aguardando ansiosamente nos últimos 40 anos', declarou (1990(f), p. 29). 
Trabalhando até o fim de sua vida, ele estava preparando, entre outras coisas, uma breve nota (1999(a), p. 379s.) sobre a prova de que o ngulo em um semic rculo é um ngulo reto, apresentada por Aristóteles (Metaf sica, 1051a 28s.), e organizando o texto de uma curta resposta a um artigo cr tico da tese principal de 1987(c). O fim veio rapidamente. Em 7 setembro de 1994, uma quarta-feira, ele foi levado a um hospital para se submeter a uma operaç o de alto risco. A operaç o foi bem-sucedida, porém revelou graves problemas inesperados. Desde ent o, as dores foram sentidas em grande parte do tempo, embora ele caracteristicamente fosse capaz de marcar sua presença em toda a ala. Por alguns dias, esteve $t$ o consciente e alerta quanto poss vel e, quando n o tinha dores, serenamente satisfeito. Morreu na manh de 17 de setembro. Seu corpo foi cremado e, algumas semanas depois, suas cinzas foram colocadas, como ele pedira, no túmulo de sua esposa, em Lainzer Friedhof, um pequeno cemitério de Viena. Em 1992, Karl Popper tornou-se cidad o honorário da cidade de Viena e seu túmulo será perpetuamente mantido por essa cidade de tantos nomes ilustres.

\section{Agradecimentos}

Gostaria de reconhecer meus débitos para com aqueles que me ajudaram na preparaç o deste estudo biográfico. Agradeço especialmente o Sr. e a Sra. A.R. Mew, testamenteiros dos bens de Karl Popper, pelas diversas informaç es e pelo grande est mulo; e também pela permiss o de citar os materiais inéditos dos Arquivos da Instituiç o Hoover e de reproduzir uma lista simplificada das publicaç es de Popper. Os agradecimentos s o também para Sir Hermann Bondi F.R.S., o Dr. A. Chmielewski, Sir Ernst Gombrich, Lady Medawar, o Dr. J. Musafia, a Universidade McMaster, o patrim nio do $3^{\circ}$ Earl Russell F.R.S., a Universidade de Harvard, o Dr. David C. Williams e a Universidade de Canterbury pela permiss o para citar textos n o publicados e informais; o Professor M.H. Hacohen por sua generosidade em me deixar tomar parte dos resultados de suas pesquisas sobre os anos de Popper em Viena; Sir Brian Follett F.R.S.; o Departamento de Arquivos da Biblioteca Brit nica de $\mathrm{Ci}$ ncia Pol tica e Econ mica e a Biblioteca da Universidade em Klagenfurt por permitirem o acesso irrestrito ao Arquivo Popper; a 
Biblioteca da Royal Society; o Sr. J. Field da seç o de relaç es públicas da Universidade de Canterbury; o Professor J. Agassi, o Dr. T. Angelidis, o Dr. O.A.S. Bueno, o Professor S.G. Houlgate, o Professor I.C. Jarvie, Mme. M.-I. Brudny-de Launay, o Sr. B. Magee, Dozent K.M. Milford, o Dr. A.F. Petersen, o Dr. J.F.G. Shearmur, o falecido Professor C.G.F. Simkin, o Professor Dr. G. W chtersh user e o falecido Professor J.W.N. Watkins pelas informaç es e cr ticas valiosas.

Alguns pequenos erros factuais presentes na vers o original deste estudo foram corrigidos nesta traduç o, mas o conteúdo da mesma n o foi de outra forma alterado. Atualizei as refer ncias bibliográficas e tentei torná-las mais acess veis aos leitores da 1 ngua portuguesa. Agradeço Otávio Bueno pelo aux lio considerável e suas diversas sugest es.

\section{Carreira Profissional}

1937-1940 Lecturer in Philosophy, Canterbury College, University of New Zealand

1941-1946 Senior Lecturer in Philosophy, Canterbury College, University of New Zealand

1945-1948 Reader in Logic \& Scientific Method, London School of Economics

1949-1969 Professor of Logic \& Scientific Method, University of London

1951-1953 Chairman, Philosophy of Science Group of the British Society for the History of Science [atualmente, British Society for the Philosophy of Science]

1958-1959 President, Aristotelian Society

1959-1961 President, British Society for the Philosophy of Science

1969-1994 Emeritus Professor of Logic \& Scientific Method, University of London

1986-1994 Senior Research Fellow, Hoover Institution on War, Revolution \& Peace [Stanford]

1986-1994 Visiting Professor, University of Vienna 


\section{Honrarias, Medalhas, e Pr mios}

1965 Knight Bachelor

1965 Prize of the City of Vienna, Geisteswissenschaften

1973 Sonning Prize of the University of Copenhagen

1976 Lippincott Award of the American Political Science Association

1976 Grand Decoration of Honour in Gold [Áustria]

1978 Dr Karl Renner Stiftung Prize of the City of Vienna

1979 Gold Medal for Distinguished Service to Science of the American Museum of Natural History [Nova York]

1980 Ehrenzeichen $\mathrm{f} \mathrm{r}$ Wissenschaft und Kunst [Áustria]

1980 Orden Pour le Mérite f r Wissenschaften und K nste [Alemanha]

1981 Dr Leopold Lucas Prize of the University of T bingen

1982 Companion of Honour

1983 Grosses Verdienstkreuz mit Stern und Schulterband [Alemanha]

1983 Ehrenring of the City of Vienna

1984 Prix Alexis de Tocqueville [Valognes]

1986 Wissenschaftsmedaille der Stadt Linz [Áustria]

1988 Xth International Prize 'Friedrich Nietzsche' [Palermo]

1989 Premi Internacional Catalunya [Barcelona]

1992 Goethe Medaille [Instituto Goethe, Munique]

1992 Kyoto Prize [Jap o]

1992 Ehrenb rger [Cidad o Honorário] der Stadt Wien

1993 Otto-Hahn-Friedensmedaille [Berlim]

1994 Open Society Prize [CEU, Praga]

\section{Participaç es como Membro ou Membro Honor rio}

1949 Membre de l'Académie Internationale de Philosophie des Sciences 
1958 Fellow of The British Academy

1964 Honorary Member, Harvard Chapter of Phi Beta Kappa

1965 Honorary Member, The Royal Society of New Zealand

1966 Foreign Honorary Member, American Academy of Arts and Sciences

1972 Honorary Fellow, London School of Economics

1974 Correspondant de l'Institut de France

1976 Fellow of The Royal Society of London

1976 Associate Member, l’Académie Royale de Belgique

1977 Honorary Member, l'Académie Internationale d'Histoire des Sciences [Paris]

1979 Honorary Member, Deutsche Akademie f r Sprache und Dichtung

1979 Honorary Member, Allgemeine Gesellschaft f r Philosophie in Deutschland

1980 Membre de l'Académie Européenne des Sciences, des Arts et des Lettres [Paris] [Delegaç o da Gr -Bretanha]

1980 Membre de l'Institut de France

1980 Honorary Fellow, Darwin College, Cambridge

1981 Socio Straniero dell'Accademia Nazionale dei Lincei

1982 Ehrenmitglied, sterreichische Akademie der Wissenschaften

1982 Honorary Research Fellow, Department of History \& Philosophy of Science, King's College [Londres]

1986 Foreign Associate, National Academy of Sciences [Washington]

1986 Ehrenmitglied, Gesellschaft der rzte Wien

1991 Emeritus Member Academia Europaea [Londres]

1991 Ehrenmitglied, Academia Scientiarum et Artium Europaea [Salzburgo]

1992 Ehrenmitglied, Hochschule f r Musik und Darstellende Kunst [Viena]

1994 Honorary Member, Scientific Council, 3rd Medical Faculty, Charles University [Praga] 


\section{$T$ tulos Honor rios}

Hon. LL.D., Chicago 1962; Hon. LL.D., Denver 1966; Hon. Lit.D., Warwick 1971; Hon. Lit.D., Canterbury [NZ] 1973; Hon. D.Litt., Salford 1976; Hon. D.Litt., The City University 1976; Dr.rer.nat.h.c., Viena 1978; Renewal of the degree of Doctor of Philosophy by the Faculty of Fundamental Sciences, Viena 1928/ 1978; Dr.phil.h.c., Mannheim 1978; Hon. D.Litt., Guelph 1978; Dr.rer.pol.h.c., Frankfurt am Main 1979; Dr.phil.h.c., Salzburgo 1979; Hon. Litt.D., Cambridge 1980; Hon. D.Sc., Gustavus Adolphus College 1981; Hon. D.Litt., Oxford 1982; Hon. D.Sc., Londres 1986; Dr.phil.h.c., Catholic University of Eichst tt 1991; Dr.phil.h.c., Madri 1991; Dr.phil.h.c., Atenas 1993; Dr.med.sc.h.c., Charles University 1994.

\section{Confer ncias Especiais}

1950 William James Lectures, Harvard University

1950 Woodward Lecture, Yale University

1956 Eleanor Rathbone Memorial Lecture, University of Bristol

1960 Annual Philosophical Lecture, Henrietta Hertz Trust, British Academy

1961Herbert Spencer Lecture, University of Oxford

1961 Shearman Memorial Lectures, University College, Londres

1963 Farnum Lecture, Princeton University

1965 Arthur Holly Compton Lecture, Washington University, St Louis

1969 Kenan Lectures, Emory University

1971 James Scott Lecture, Royal Society of Edinburgh

1972 Romanes Lecture, University of Oxford

1973 Henry Dan Broadhead Memorial Lecture, University of Canterbury, Christchurch

1973Herbert Spencer Lecture, University of Oxford 
1977Darwin Lecture, Darwin College, Cambridge

1978 Obert C. Tanner Lecture, University of Michigan

1979Frank Nelson Doubleday Lecture, Smithsonian Institution

1981 J. B. Morrell Memorial Lecture, University of York

1986 Medawar Lecture, Royal Society of London

1989 Vera \& Walter Morris Foundation Philosophy of Science Lecture, University of Arkansas for Medical Sciences, Little Rock

\section{Confer ncias Dedicadas Filosofia de Popper}

1968 Simposio de filosof a de la ciencia: homenaje a Karl R. Popper, Burgos

1969 University centennial symposium in honor of Sir Karl Popper, Boston

1973 Methodologies: Bayesian \& Popperian, Columbia SC

1980 Symposium on the philosophy of Sir Karl Popper, Londres

1980 Symposium on the philosophy of Sir Karl Popper, Beijing

1981 Karl Popper et la science d'aujourd'hui, Cerisy-la-Salle

1981 Karl Popper: science et philosophie, Estrasburgo

1981 Popper e la societ aperta, Assisi

1982 The open society and its friends, Nova York

1983 'Individuale-collettivo', Club Turati, Turim

1983 Wiener Popper-Symposium, Viena

1984 V Jornades de filosof a. La filosof a de K. Popper, Barcelona

1984 One-day conference on the Philosophy of Karl Popper, University of Manchester [realizada anualmente em Manchester, Coventry ou Londres]

1984 Symposium on the philosophy of Sir Karl Popper, Madri

1985 Kritischer Rationalismus Heute II, Arnoldsheim 
1986 Popper and political thought, Edimburgo

1987 Conference on the philosophy of Karl Popper, Wuhan

1994 L'epistemologia de Karl Popper, Cesena

1994 Teor a y metodo de las ciencias sociales, Cidade do México

1995 Karl Popper 1902-1994, Varsóvia

1995 Conference to celebrate the fiftieth anniversary of the publication of The open society and its enemies, Praga

\section{Bibliografia}

1934(b) Logik der Forschung. Viena: Julius Springer.

1938(a) A set of independent axioms for probability. Mind 47, 275277. (Ver também p. 415 e 552, para correç es.)

1945(b) The open society and its enemies. Volume I. The spell of Plato. Londres: George Routledge. Trad. de Milton Amado: A sociedade aberta e seus inimigos, Volume I. Belo Horizonte: Itatiaia, S o Paulo: EDUSP, 1974.

1945(c) The open society and its enemies. Volume II. The high tide of prophecy: Hegel, Marx, and the aftermath. Londres: George Routledge. Trad. de Milton Amado: A sociedade aberta e seus inimigos, Volume I. Belo Horizonte: Itatiaia, S o Paulo: EDUSP, 1974.

1945(e) (Com outros) Research and the University. Christchurch: Caxton Press.

1947(b) Logic without assumptions. Proc. Aristotelian Soc. 47, 251-292.

1950(b) Indeterminism in quantum physics and in classical physics I. Brit. J. Phil. Sci. 1, 117-133.

1950(c) Indeterminism in quantum physics and in classical physics II. Brit. J. Phil. Sci. 1, 173-195.

1952(a) The open society and its enemies. $2^{\mathrm{a}}$ ed. Londres: Routledge \& Kegan Paul.

1954(d) Degree of confirmation. Brit. J. Phil. Sci. 5, 143-149.

1955(b) Two autonomous axiom systems for the calculus of probabilities. Brit. J. Phil. Sci. 6, 51-57. 
1956(b) The arrow of time. Nature 177, 538.

1957(g) The poverty of historicism. Londres: Routledge \& Kegan Paul. Trad. de Octanny Silveira da Mota \& Leonidas Hegenberg: A mis ria do historicismo. S o Paulo: Cultrix e EDUSP, 1980.

1959(a) The logic of scientific discovery. Londres: Hutchinson. Trad. de Leonidas Hegenberg \& Octanny Silveira da Mota: A l gica da pesquisa cient fica. S o Paulo: Cultrix e EDUSP, 1975.

1962(f) Julius Kraft 1898-1960. Ratio (Oxford) 4, p. 2-12.

1963(a) Conjectures and refutations: the growth of scientific knowledge. Londres: Routledge \& Kegan Paul. Trad. de Sérgio Bath: Conjecturas e refutaç es (O progresso do conbecimento cient fico). Bras lia: Coleç o Pensamento Cient fico, Editora da Universidade de Bras lia, 1981.

1967(e) Zum Thema Freiheit. In: Die Philosophie und die Wissenschaften: Simon Moser zum 65. Geburtstag (ed. E. Oldemeyer), p. 1-12. Meisenheim/Glan (Alemanha): Anton Hain.

1967(k) Quantum mechanics without 'the observer'. In: Quantum theory and reality (ed. M. Bunge), p. 7-44. Berlim, Heidelberg \& Nova York: Springer.

1968(q) Birkhoff and von Neumann's interpretation of quantum mechanics. Nature 219, 682-685.

1970 $\left(\mathrm{z}_{11}\right)$ unsigned obituary notice for Professor Rudolf Carnap. The Times, 57973, 17/Set/1970, 12.

1971(m) The philosophy of Russell: II - discussion among Karl Popper, Peter Strawson, and Geoffrey Warnock. In: Modern British philosophy (ed. B. Magee), p. 131-149. Londres: Secker \& Warburg.

1972(a) Objective knowledge: an evolutionary approach. Oxford: Clarendon Press. Trad. de Milton Amado: Conbecimento objetivo. Uma abordagem evolucion ria. Belo Horizonte: Itatiaia, S o Paulo: EDUSP, 1975.

1976(g) Unended quest: an intellectual autobiography. Londres: Fontana. Trad. de Leonidas Hegenberg \& Octanny Silveira da Mota: Autobiografia intelectual. S o Paulo: Cultrix e EDUSP, 1977. 
1976(h) A note on verisimilitude. Brit. J. Pbil. Sci. 27, 147-159.

1977(u) (Com J.C. Eccles) The self and its brain. An argument for interactionism. Berlim, Heidelberg, Londres \& Nova York: Springer International. Trad. de S lvio Meneses Garcia, Helena Cristina Fontenelle Arantes \& Aurélio Osmar Cardoso de Oliveira: $O$ eu e seu c rebro. O c rebro e o pensamento. Bras lia: Editora da Universidade de Bras lia, 1992.

1978(z) Natural selection and the emergence of mind. Dialectica 32, 339-355.

1979(a) Objective knowledge: an evolutionary approach. 2a ed. Oxford: Clarendon Press.

1979( $\left.\mathrm{z}_{2}\right)$ Die beiden Grundprobleme der Erkenntnistheorie (ed. T.E. Hansen). $\mathrm{T}$ bingen: J.C.B. Mohr (Paul Siebeck).

1982(a) The open universe: an argument for indeterminism (ed. W.W. Bartley III). Londres: Hutchinson. Trad. de Nuno Ferreira da Fonseca: $O$ universo aberto. Lisboa: Publicaç es Dom Quixote, 1988.

1982(b) Quantum theory and the schism in physics (ed. W.W. Bartley III). Londres: Hutchinson. Trad. de Nuno Ferreira da Fonseca: A teoria dos quanta e o cisma na f sica. Lisboa: Publicaç es Dom Quixote, 1989.

1983(b) Realism and the aim of science (ed. W.W. Bartley III). Londres: Hutchinson. Trad. de Nuno Ferreira da Fonseca: 0 realismo e 0 objetivo da ci ncia. Lisboa: Publicaç es Dom Quixote, 1987.

1983(f) (Com D.W. Miller) A proof of the impossibility of inductive probability. Nature 302, 687s.

1986 $\left(\mathrm{z}_{3}\right)$ A new interpretation of Darwinism [primeira Confer ncia Medawar, apresentada em 12 junho 1986]. N o publicado.

1987(c) (Com D.W. Miller) Why probabilistic support is not inductive. Phil. Trans. R. Soc. Lond. A 321, 569-591.

1987(t) Popper versus Copenhagen. Nature 328, 675.

1990(f) A world of propensities. Bristol: Thoemmes. Trad. de Teresa Barreiros \& Rui G. Feijó: Um mundo de propens es. Lisboa: Editorial Fragmentos, 1991.

1990(g) Pyrite and the origin of life. Nature 344, 387. 
1992 $\left(\mathrm{z}_{18}\right)$ Otkrytoie obschestwo i iego wragi. Moscou: Soros Foundation.

1992 $\left(\mathrm{z}_{21}\right)$ Contribution to programme note, concert \#44 (5/Ago/1992). Paisley International Organ Festival.

1994(e) Logik der Forschung. 10th edition. T bingen: J.C.B. Mohr (Paul Siebeck).

1994(r) The myth of the framework. In defence of science and rationality (ed. M.A. Notturno). Londres: Routledge.

1994(x) (Com D.W. Miller) Contributions to the formal theory of probability. In: Patrick Suppes: scientific philosopher (ed. P. Humphreys). Volume I. Probability and probabilistic causality, p. 3-23. Dordrecht: Kluwer.

1994(y) Alles Leben ist Probleml sen: ber Erkenntnis, Geschichte und Politik. Munique: Piper.

1994 $\left(\mathrm{z}_{12}\right)$ The Prague Lecture. In: Karl Popper in Prague: In Memoriam, p. 12-15. Praga: 3rd Medical Faculty, Charles University, and Central European University Foundation.

1996( $\left.\mathrm{z}_{2}\right)$ The lesson of this century. Karl Popper interviewed by Giancarlo Bosetti. Londres: Routledge.

1999(a) The world of Parmenides. Essays on the pre-Socratic enlightenment (ed. A.F. Petersen). Londres: Routledge.

1999(h) All life is problem solving. Londres: Routledge. Trad. de Paula Taipas: A vida aprendizagem. Lisboa: Ediç es 70, 2001.

\section{Refer ncias a Outros Autores}

Agassi, J. (1993). A philosopher's apprentice. In: Karl Popper's workshop. Amsterdam \& Atlanta: Rodopi.

Ballentine, L.E. (1970). The statistical interpretation of quantum mechanics. Rev. Mod. Phys. 42, 358-381.

Bar-Hillel, Y. \& Carnap, R. (1954). Semantic information. Brit. J. Phil. Sci. 4, 145-157. 
BARTLEY, W.W., III (1962). The retreat to commitment. Londres: Chatto \& Windus.

. (1982). A Popperian harvest. In: P. Levinson (Ed.). In pursuit of truth. Essays in honour of Karl Popper's 80th birthday, 249-289. Atlantic Highlands: Humanities.

Beaglehole, J. C. [J. C. B.] et al. [A .E. C., R. M. C. \& J. M. McE.] (1952) Three obituary notices for I.L.G. Sutherland. J. Polynesian Soc. 61, 120-129.

Berkeley, G. (1721). De motu. Londres: Tonson. Traduç o para a 1 ngua inglesa em D. M. Jesseph (Ed.) De motu E The analyst, p. 73-107. Dordrecht: Kluwer.

Bernard, C. (1865). Introduction l' tude de la $m$ decine exp rimentale. Paris: Bailli re.

Bondi, H. (1992). The philosopher for science. Nature 358, 363. 1995 Sir Karl Popper's impact on the scientific community. In: Tributes paid at the Memorial Celebration for Sir Karl Popper, 12 December 1994, p. 5-7. Londres: London School of Economics.

Collett, M. J. \& Loudon, R. (1987). Analysis of a proposed crucial test of quantum mechanics. Nature 326, 671s.; 328, 675s.

Crawshay-Williams, R. (1970). Russell remembered. Londres, Nova York e Toronto: Oxford University Press.

DAHRENDORF, R. (1995). LSE: a history of the London School of Economics and Political Science, 1895-1995. Oxford: Oxford University Press.

Delahaye, J.-P. (1994) Information, complexit et hasard. Paris: Herm s.

Duhem, P. M. M. (1906). La th orie physique, son objet, sa structure. Paris: Chevalier et Rivi re. Traduç o para a 1 ngua inglesa: The aim and structure of physical theory. Princeton: Princeton University Press.

ECcles, J.C. (1982). My living dialogue with Popper. In: P. Levinson (Ed.) In pursuit of truth. Essays in honour of Karl Popper's 80th birthday, p. 221-236. Atlantic Highlands: Humanities.

Gardner, W.J., Beardsley, E. T., \& Carter, T. E. (1973). A bistory of the University of Canterbury, 1873-1973. Christchurch: University of Canterbury.

Geier, M. (1994). Karl Popper. Hamburg: Rowohlt.

Gellner, E.A. (1959). Words and things. Londres: Gollancz. 
1996. Karl Popper - the thinker and the man. In: S. Amsterdamski (Ed.). The significance of Popper's thought. Proceedings of the conference Karl Popper 1902-1994, March 10-12 1995, Graduate School of Social Research, Warsaw, p. 75-85. Amsterdam \& Atlanta: Rodopi.

Godsiff, P. (1972). Sir Karl Popper in New Zealand. The NZ listener, 24 January 1972, 12.

Gombrich, E. H. J. (1999) Personal recollections of the publication of The Open Society. In: I. C. Jarvie \& S. Pralong (Ed.). Popper's Open Society after fifty years: the continuing relevance of Karl Popper, p. 17-27. Londres: Routledge.

Grattan-Guinness, I. (1992). Russell and Karl Popper: their personal contacts. Russell n.s. 12, 3-18.

Hacohen, M. H. (1996). Karl Popper in exile: The Viennese progressive imagination and the making of The Open Society. Philosopby of the Social Sciences 26, 452-492.

Hadamard, J. (1898). Les surfaces courbures opposées et leur lignes géodésiques. J. Math. Pures Appl. (5) IV, 27-73.

Hansen, T.E. (1974). Bibliography of the writings of Karl Popper [até 1973]. In: P. A. Schilpp (Ed.) The philosophy of Karl Popper, p. 1201-1287. La Salle: Open Court.

Havel, V. (1995). Karl Popper's The open society and its enemies in the contemporary global world [The Chancellor's Lecture for 1995 at the Victoria University of Wellington]. Stout Centre Rev. 5, 4-6.

Jammer, M. (1974). The philosophy of quantum mechanics. Nova York: Wiley.

Jennings, H.S. (1906). The behaviour of the lower organisms. Nova York: Columbia University Press.

Kiesewetter, H. (1997). Fundamentos éticos da filosofia de Popper. In: A. O'Hear (Ed.). Karl Popper: filosofia e problemas, p. 325-340. S o Paulo: Editora UNESP.

Kraft, J. 1957 Von Husserl zu Heidegger. Kritik der ph nomenologischen Philosophie. $2^{\mathrm{a}}$ ed. Frankfurt a. Main: Verl. ffentlich. Leben.

KuHn, T.S. (1962). The structure of scientific revolutions. Chicago: University of Chicago Press. Trad. de Beatriz Vianna Boeira e Nelson Boeira: A estrutura das revoluç es cient $f$ cas. S o Paulo: Perspectiva, 1975. 
KuHn, T. S. (1970). Logic of discovery or psychology of research? In: I. Lakatos \& A.E. Musgrave (Ed.) Criticism and the growth of knowledge, p. 123. Cambridge: Cambridge University Press. Trad. de Octavio Mendes Cajado: A cr tica e o desenvolvimento do conbecimento. S o Paulo: Cultrix e EDUSP, 1979.

Lakatos, I. (1974). Popper on demarcation and induction. In: P.A. Schilpp (Ed.). The philosophy of Karl Popper, p. 241-273. La Salle: Open Court.

LANDÉ, A. 1955 Foundations of quantum theory. New Haven: Yale University Press.

Leblanc, H. (1989). Popper's formal contributions to probability theory. In: M.A. Notturno (Ed.), Perspectives on psychologism, p. 341-367. Leiden, Nova York, Col nia: Brill.

Liebig, J. von (1865). Induction und Deduction. Munique: K nigl. Akademie.

Magee, B. (1997). Confessions of a philosopher. Londres: Weidenfeld \& Nicolson.

Medawar, P. B. (1967). Hypothesis and imagination. In: The art of the soluble. Londres: Methuen.

(1986). Memoirs of a thinking radish: an autobiography. Oxford: Oxford University Press.

Menger, K. (1974). Postscript to the English edition of Morality, decision and social organization (1934). Dordrecht: Reidel.

Neumann, J. von (1931). Mathematische Grundlagen der Quantenmechanik. Berlim: Springer. Traduç o para a I ngua inglesa: Mathematical foundations of quantum mechanics. Princeton: Princeton University Press, 1955.

Pauli, W. (1954). Wahrscheinlichkeit und Physik. Dialectica 8, 112-124.

Perutz, M. F. (1986). A new view of Darwinism. New Scientist, 2/Out/ 1986, 36-38.

PolanyI, M. (1958). Personal knowledge. Towards a post-critical philosophy. Londres \& Henley: Routledge \& Kegan Paul.

Redhead, M. L. G. (1997). Popper e a teoria qu ntica. In: A. O’Hear (Ed.). Karl Popper: filosofia e problemas, p. 193-209. S o Paulo: Editora UNESP. 
RéNYI, A. (1955). On a new axiomatic theory of probability. Acta Math. Hungar. 6, 286-335.

Russell, B. A.W. (1948). Human knowledge. Its scope and limits. Londres: Allen \& Unwin. Trad. de Le nidas Gontijo de Carvalho: Conbecimento bumano. 2 vols. S o Paulo: Nacional.

Schilpp, P. A. (Ed.) (1949). Albert Einstein: philosopher-scientist. Nova York: Tudor. 1974 The philosophy of Karl Popper. La Salle: Open Court.

SCHr DINGer, E. (1967). What is life? E Mind and matter. Cambridge: Cambridge University Press. Trad. de Jesus de Paula Assis \& Vera de Paula Assis: O que vida? O aspecto vivo da c lula. S o Paulo: Editora UNESP, 1997.

Schroeder-Heister, P. (1984). Popper's theory of deductive inference and the concept of a logical constant. Hist. Phil. Logic 5, 79-100.

Shearmur, J.F . G. (1996). The political thought of Karl Popper. Londres: Routledge.

Simkin, C. G. F. (1993). Popper's views on natural and social science. Leiden, Nova York, Col nia: Brill.

Soros, G. et al. (1995). Sir Karl Popper receiving the Open Society Prize. In: Karl Popper in Prague: In Memoriam, p. 32-37. Praga: 3rd Medical Faculty, Charles University e Central European University Foundation.

Sotheby's (1995). The Library of Sir Karl Popper [catálogo de um leil o programado para 19/mai/1995]. Londres: Sotheby's.

Tarski, A. (1936). O pojciu wynikania logicznego. Przeglad Filozoficzny 39, 58-68. Traduç o para a 1 ngua inglesa: On the concept of logical consequence. In: A. Tarski Logic, semantics, metamathematics, p. 409-420. Oxford: Clarendon Press, 1956.

VILLE, J. (1939). tude critique de la notion de collectif. Paris: Gauthier-Villars.

W chtersh user, G. 1988 Before enzymes and templates: theory of surface metabolism. Microbiol. Rev. 52, 452-484.

W Chtersh user, G. (1995). Karl Popper, mentor of science - a personal view. In: Tributes paid at the Memorial Celebration for Sir Karl Popper, 12 December 1994, p. 21-25. Londres: London School of Economics. 
W Chtersh user, G. (1997). The origin of life and its methodological challenge. J. Theor. Biol. 187, 483-494.

Watkins, J. W. N. (1997). Popper e o darwinismo. In: A. O’Hear (Ed.). Karl Popper: filosofia e problemas, p. 227-245. S o Paulo: Editora UNESP. Whewell, W. 1840 Philosophy of the inductive sciences. Londres: Parker. . On the philosophy of discovery. Londres: Parker.

\section{Notas}

* Direito de traduç o gentilmente cedido pela Royal Society de Londres. Traduç o de Robinson Guitarrari e Caetano Ernesto Plastino.

** Departamento de Filosofia da Universidade de Warwick

† Esta memória biográfica foi escrita para a Royal Society de Londres e publicada em Biographical Memoirs of Fellows of the Royal Society 43, 1997, p. 367-409.

$\dagger$ Refer ncias neste formato est o na lista abreviada das publicaç es de Popper, no final deste ensaio. Sempre que poss vel, as refer ncias foram feitas $\mathrm{s}$ reimpress es de coleç es facilmente dispon veis, $\mathrm{n}$ o $\mathrm{s}$ publicaç es originais, e a cap tulos e a números de seç es, em vez de números de páginas. Refer ncias ao arquivo Hoover s o da forma $[x . z]$, onde $x$ é o número da caixa e $z$ é o número da pasta. Para ser breve, omito muitas refer ncias a Unended quest [Autobiografia intelectual], texto ao qual recorri com liberdade. 